\title{
"RISING WITH THE TIDE OF \\ HISTORY": THE AGE OF SAIL AS \\ INDUSTRIAL ALIBI
}

Claire Campbell

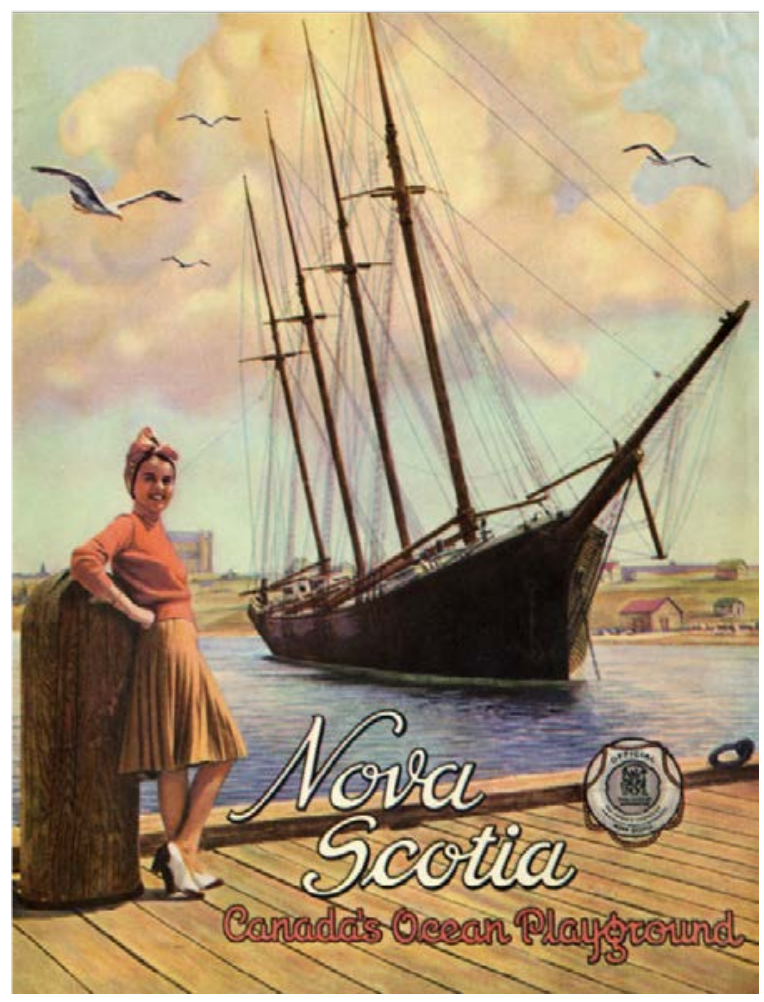




\section{NICHE}

Network in Canadian History and Environment

Department of History

York University

2140 Vari Hall

4700 Keele Street

Toronto, Ontario, M3J 1P3

http://niche-canada.org

Campbell, Claire. "“Rising with the Tide of History”: The Age of Sail as Industrial Alibi" Papers in Canadian History and Environment, no. 2 (May 2019): 1-37.

DOI: dx.doi.org/10.25071/10315/36212

\section{(C) (1) @}

"'Rising with the Tide of History": The Age of Sail as Industrial Alibi" by Claire Campbell is licensed under a Creative Commons AttributionNonCommercial 4.0 International License.

\section{Papers in Canadian History and Environment}

Editors: Jennifer Bonnell, Sean Kheraj, and Owen Temby

Papers in Canadian History and Environment is an open-access, peerreviewed occasional research paper series published by NiCHE. It features article-length research papers that examine any aspect of the historical relationships among people and the rest of nature in Canada.

ISSN 2561-54 
"RISING WITH THE TIDE OF HISTORY": THE AgE OF SAIL AS INDUSTRIAL ALIBI

Claire Campbell

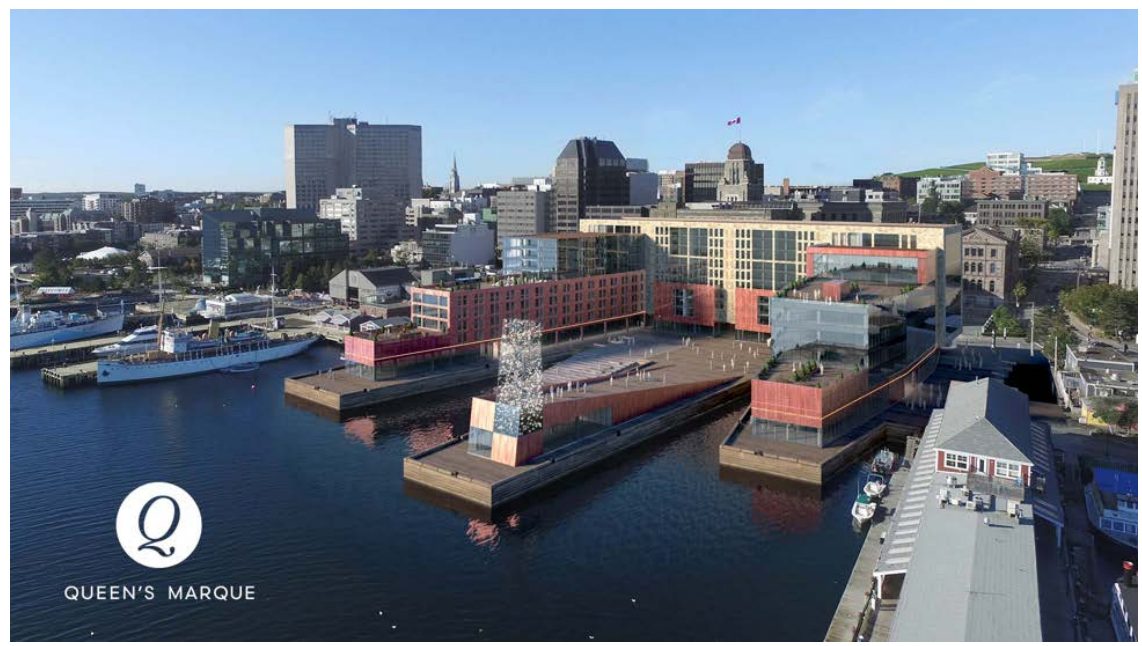

Figure 1. Proposed design, Queen's Marque, queensmarque.com. Courtesy The Armour Group Limited.

IN THE FALL OF 2016, construction began on the third major condominium project on the twenty-first-century Halifax harbour. Queen's Marquelike Bishop's Landing (2003) and the ongoing King's Wharf (2010) before it-repackages the core of the city's waterfront into the opportunity to purchase property "pressed up against the ocean." Throughout its marketing Queen's Marque stresses its local identity as a way to justify its occupation of the waterfront, in everything from its name to its motifs and materials (Figure 1). This section of the Halifax harbourfront had, in fact, been reserved for the Crown since the end of the eighteenth century. The design of the new project includes two arms meant to invoke hulls "breaching the waves," with a harbour light installation between them. And reaching further, the promotional materials situate Queen's Marque in a 


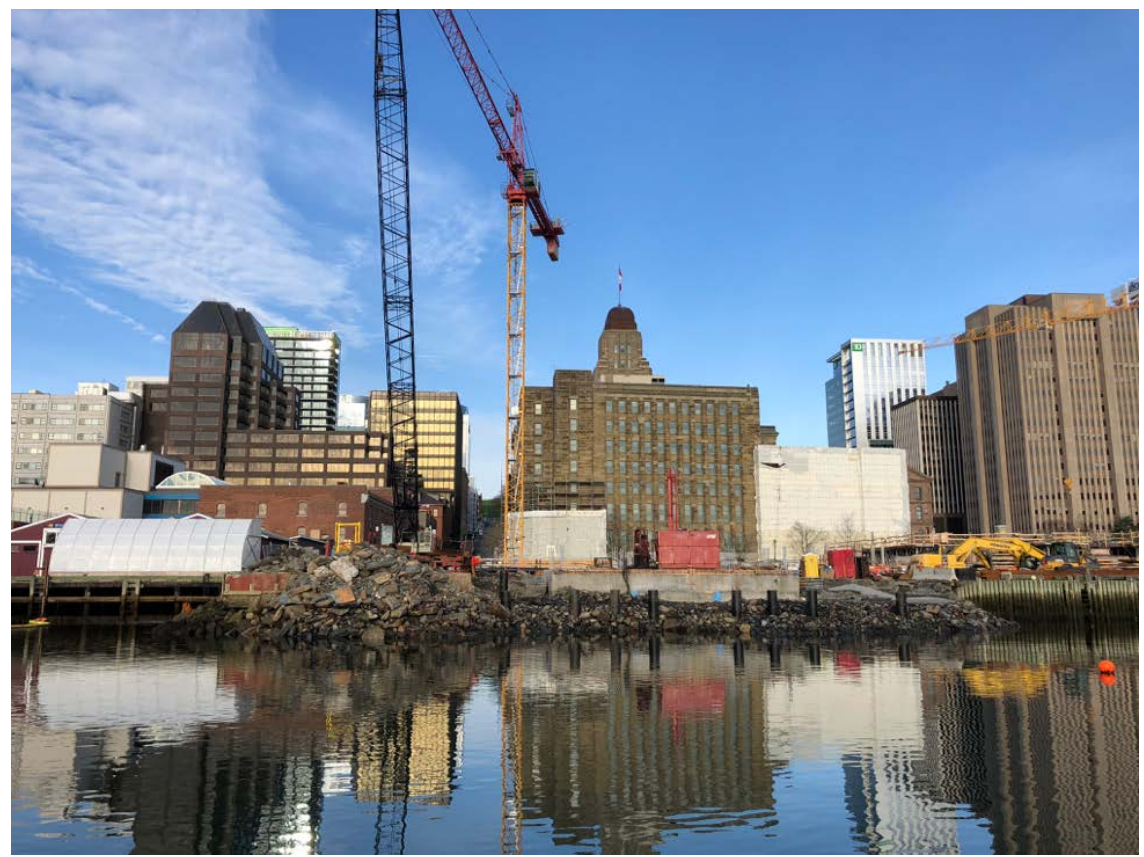

Figure 2. Queen's Marque under construction, 6 May 2018. Photo by the author. tradition of regional opportunity-or opportunism. Atlantic Canada, this new development tells us, "rose with the tide of history," when privateers wielded the royal marque to "legally claim the bounty of this land and establish settlements on it." Its twenty-first-century namesake promises to see the harbourfront, and presumably the city, rise again in "a new era of growth and prosperity in Atlantic Canada."

The expression "rising with the tide of history" suggests an eventual triumph, and with wonderfully passive inevitability. It asks nothing of us, and instead invokes a presumably renewable source of energy, in tidal power. Indeed, the Bay of Fundy-only an hour's drive from Halifax-sees the highest tides in the world. There are, however, three substantial and troubling ironies here. For one, tidal generation in Fundy remains at the research stage, despite a century of proposals, because the tides have proven too strong for turbines. ${ }^{2}$ Second, construction on the cofferdams at Queen's Marque has already had to contend with rising sea levels, propelled 
by climate change brought on by the use of fossil fuels (Figure 2) ${ }^{3}$ Third, and most importantly, even as projects like Queen's Marque attempt to revive and display elements of coastal history-in ways that suggest that this history offers inspiration for more appropriate and sustainable ways of coastal living - the province of Nova Scotia, like its counterparts in the federation and the federal government of Canada, remains committed to aggressively pursuing fossil fuel extraction offshore. ${ }^{4}$ It is worth remembering that a rising tide can bring trepidation as well as opportunity. Here it carries a tangled history of power and unresolved contradictions.

Canada has more coastline than any other country in the world: according to Statistics Canada, 243,042 kilometres on three oceans. Yet we have never had an environmental history of Canada as a coastal state, one that considers the role of coastlines in the national project or our national identity. ${ }^{5}$ In both popular and scholarly histories of Canada (and the United States, for that matter) coastlines feature most prominently in the age of "discovery" and the age of sail. They then fade from the story as national attention turns to continental expansion, from sea to sea-a moment that coincides precisely with the acceleration of the Anthropocene. I want to argue instead that the Atlantic coast has been highly useful to Canada as a nation-state after Confederation in 1867. As at Queen's Marque, the age of sail has served to legitimate the development ethos so central to both the nation-building project and the Anthropocene writ large.

As we see in debates over pipelines in and from the west, the development ethos continues to define the prevailing view of "national interest," as it has done since the mid-nineteenth century. But this story is not only a western (or northern) one. There has been a concurrent commitment to seeing the Atlantic horizon as a frontier; as historian Arthur Lower wrote exaltedly in 1953, "For nothing can eliminate our frontier, that vast land to the north there.... And as to the sea!... Is it not a 
frontier, too, which calls out all the resources and ingenuity and adaptiveness of man?" ${ }^{\prime}$ At the same time, as with images of northern wilderness or mountain parks, we have continued to depict the Atlantic coastline in ways that suggest a harmony with a nature greater than ourselves. The schooner-most famously, but not exclusively, the Bluenose-is quintessentially Canadian, not because of the dime or a Heritage Minute: rather, it appears on the dime because of how successfully it embodies this phenomenon of romancing extraction. The enormous investments in and catches from the Grand Banks fishery - the site and symbol, in many ways, of environmental crisis in Atlantic Canada by the end of the twentieth century -becomes the grace and exhilaration of a single wooden craft under sail. Where and why this happens deserves closer scrutiny.

This article finds a pattern of using references to the age of sail to convey economic opportunity-calling out all our resources and ingenuity-in concert with natural beauty and environmental resilience. This suggests that the tall ship has supplied an environmental alibi to our extractive economy. An alibi places us in another place, and in this case, another time. An icon of renewable energy (the wind-powered sailing ship) in a non-industrial setting (the wooden wharf or oceanic horizon) offers a visually appealing alternative to or stand-in for contemporary, unsustainable development (notably fossil fuels). This is, of course, the very essence of a usable past. While sailing ships have long been used to market Nova Scotia in tourism, this visual sleight-of-hand takes on a more insidious role in an era of accelerated offshore exploration and global climate change, when one generation of energy history is used to simultaneously represent, distract from, and license another. An antiquated technology becomes highly valuable as a rationalizing metaphor, one that supports quintessential industrial projects of growth by presenting an 
appealing, benign, and vaguely pre-industrial relationship with the natural world. It supplies a fictional timeline running parallel to our own, from past glory to future prosperity-rising again with the tide-without addressing the past or present of our industrial reality.

Studying how nature has been depicted (in art, photography, or design) can reveal how nature has been seen in the past, or how people wanted to see nature in order to justify a desired relationship with, or use of, that nature. The images assembled here span a century of staged, promotional, public images created by corporations and different levels of government; between maps, photographs, and architectural plans; and most importantly, between message and landscape, between how a coastline is imagined and represented, and how it is used and occupied. It is the very eclecticism of these images, taken from across time and genre, that reveals the rhizomic commitment to resource capitalism, and the success of its alibi. $^{7}$

It also undermines the notion that Atlantic Canada was excised from the prevailing arc of national development. In that narrative (by those at home and away), the east coast had served as a useful beachhead for empire, but after Confederation it became a foil to the country's western and northern trajectory: excluded from and occasionally resentful of the defining industrial projects of grain and bitumen, and, wilting from outmigration, politically marginalized. Then, in the later part of the twentieth century, the region experienced several dramatic episodes that seemed to confirm the limits and unsustainability of an extractive resource economy. Coal mines were shuttered in the 1960s. The ground-fisherywhich had attracted European fishers for five hundred years-was closed in 1992. The disastrous "tar ponds" in Sydney, Nova Scotia-pools of decades-old steel and mining waste that constituted the largest hazardous waste site in the country-drew national attention amid repeated clean-up 


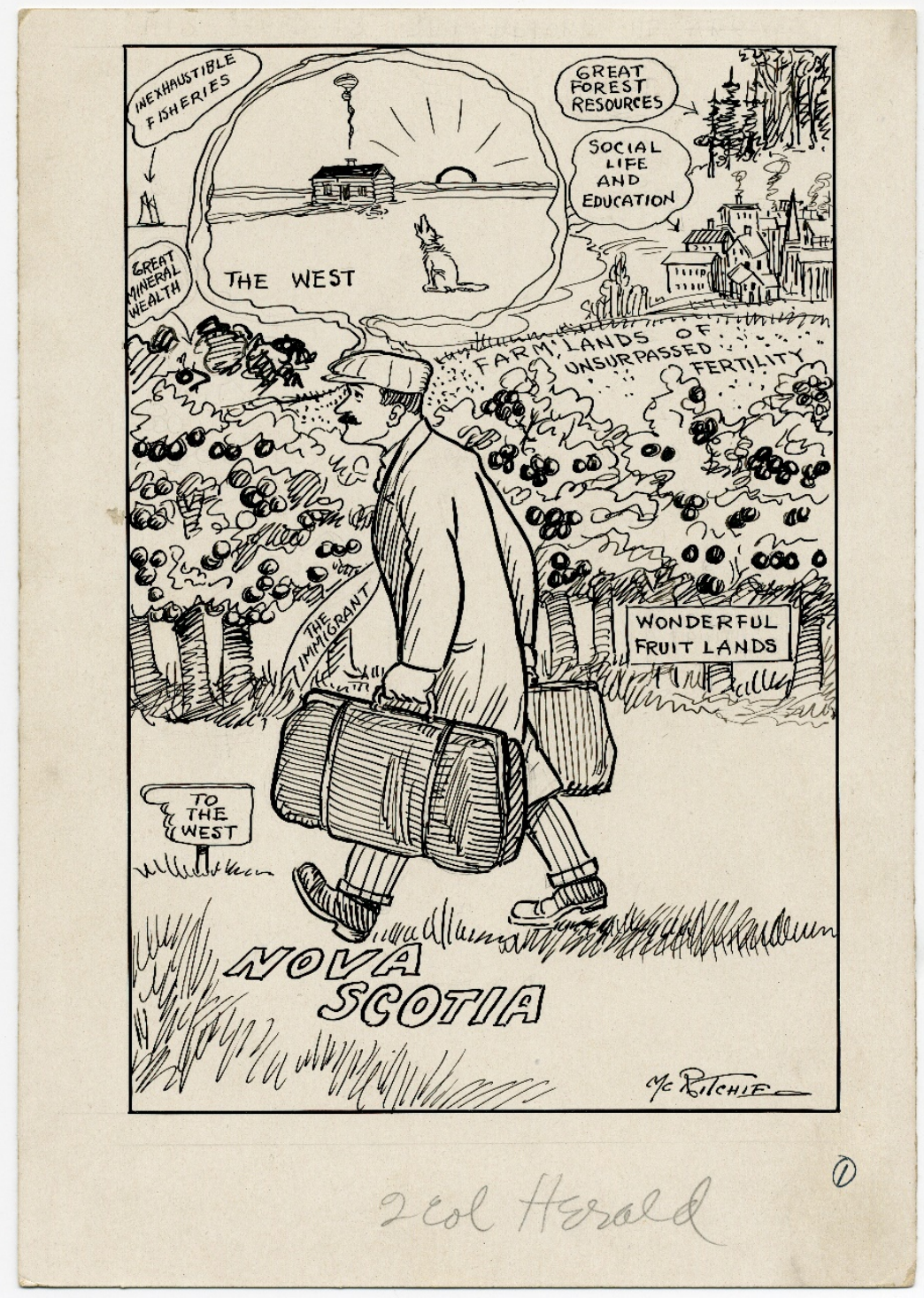

Figure 3. Donald McRitchie, "And he passes by" (1926). Acc. 1900.007-RIT/142, Donald M. McRitchie fonds, Acadia University Archives. 
efforts. Atlantic Canada seemed to be leading the country into a postindustrial era, whether it liked it or not. ${ }^{8}$

The key word, though, is seemed. Atlantic Canada has remained as committed as any other region in Canada to exhorting "men with enterprise and capital" ${ }^{\prime}$ to develop its natural resources. In Donald McRitchie's 1926 cartoon, Nova Scotia promises a veritable kaleidoscope of resource landscapes and income opportunities, from mining to agriculture to fishing, along with comfortably established social institutions (Figure 3). All this is in stark contrast with the hostile isolation (and setting sun) of the prairie. Like their western rivals, though, these Nova Scotian environments and the wealth they promised were surely "inexhaustible." Unsurprisingly, there is no reference to the actual state of the coal industry, which at the time of this cartoon was the site of the worst labour conflict in Canada. ${ }^{10}$

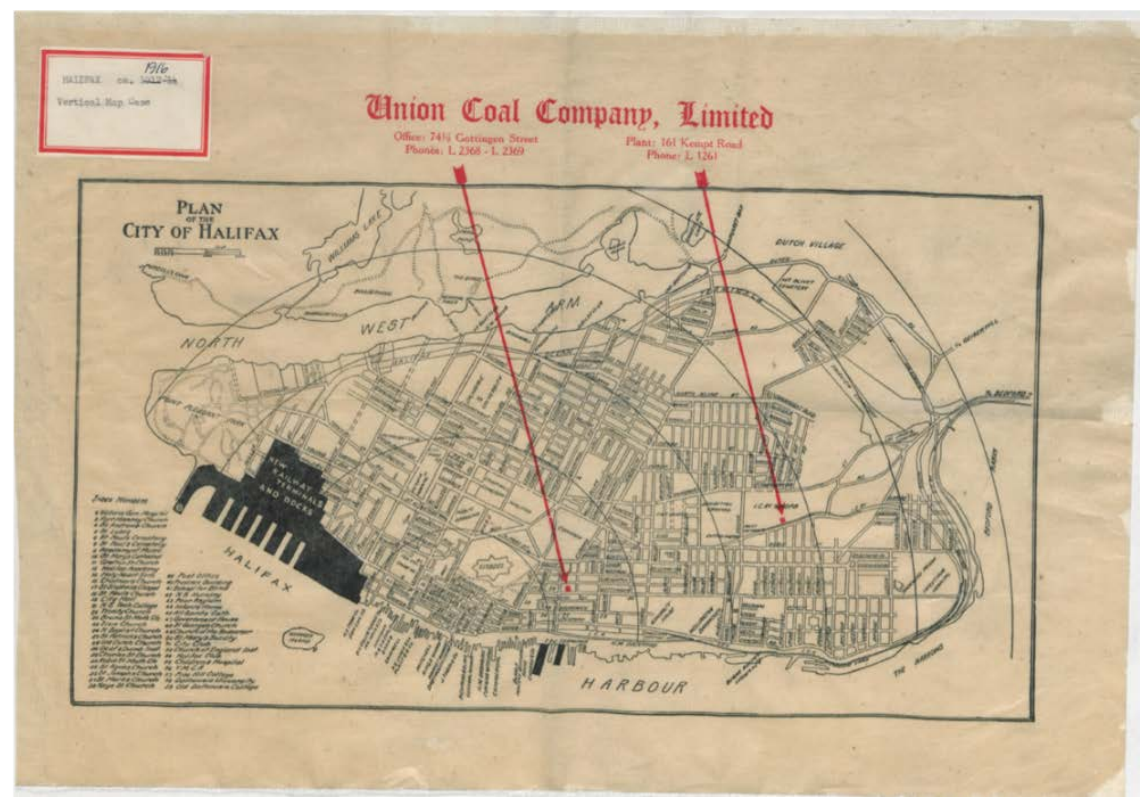

Figure 4. Plan of the City of Halifax, Union Coal Company (1916). V6 240, Nova Scotia Archives (NSARM). 


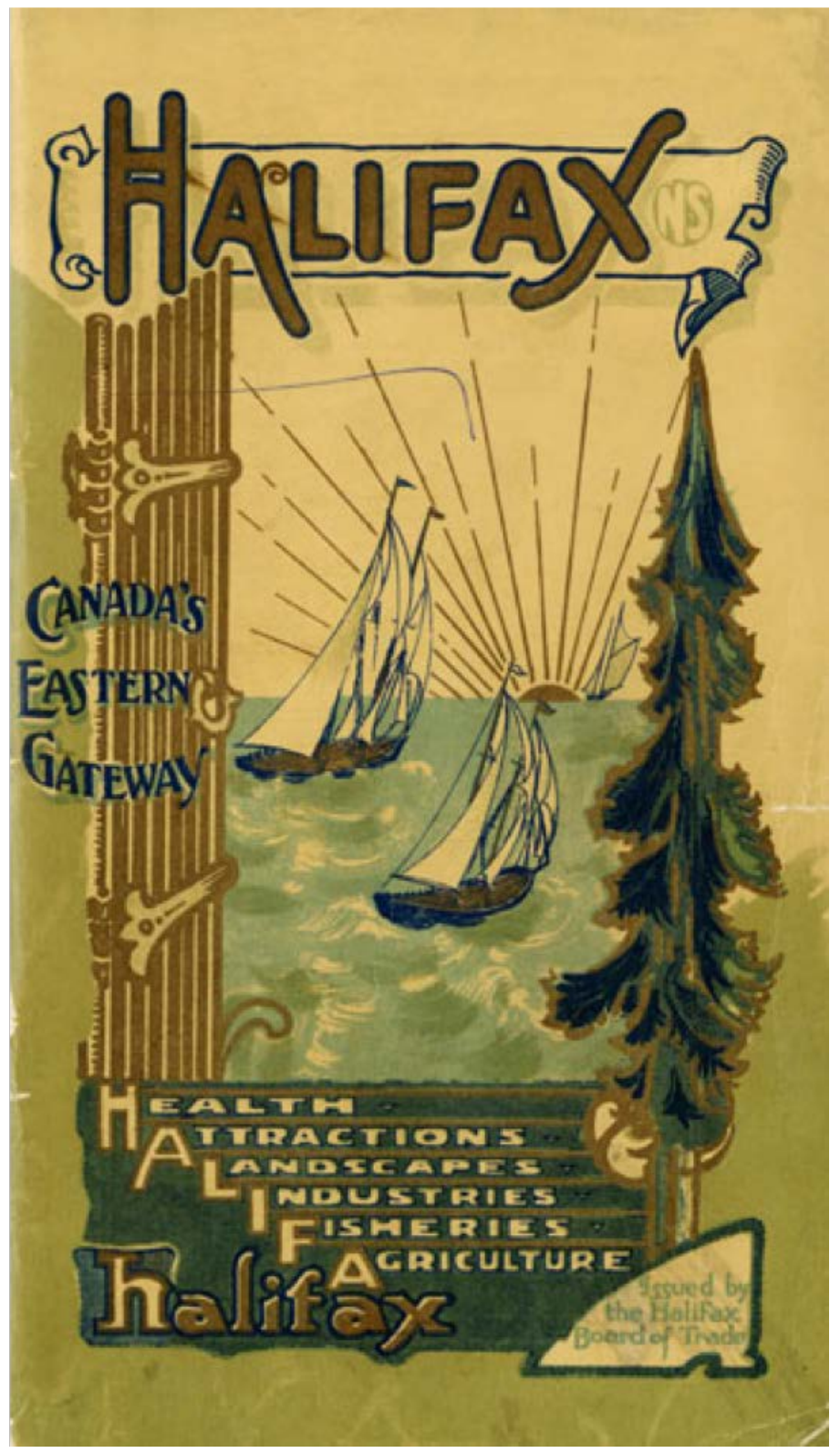

Figure 5. "Beautiful Halifax"/"Halifax: Canada's Eastern Gateway," Halifax Board of Trade (1921). No. 6a, H12, F107, NSARM. 
Meanwhile, the city of Halifax was in the midst of an unprecedented construction project to create a new port facility that included a line of deep-water terminals and a rail line cut through the peninsula to encircle the city. This was part of a decades-long effort to position itself as the country's eastern gateway, a phrase still invoked by industry representatives today. ${ }^{11}$ Halifax had been a coaling station for the Royal Navy for half a century, ${ }^{12}$ but this represented a much larger commitment of peninsular space and political capital to the infrastructure of fossil fuels. Suppliers of coal and coal oil regularly advertised their services in city directories; the 1916 directory, for example, listed at least six coal and four oil suppliers within a block of the downtown waterfront alone. ${ }^{13}$ That same year, while the Union Coal Company published its map of Halifaxhelpfully pointing out its office and plant while underscoring, in massed black, the anticipated new terminals and rail lines-Imperial Oil began construction on a refinery and company town across the harbour in Dartmouth at what it named Imperoyal (Figure 4). All this to say that by the second decade of the twentieth century, Halifax was deeply and physically invested in the traffic of coal and petroleum.

And yet even with these classic examples of heavy industry in the forefront-literally-of the port city, it was already cultivating a windpowered alibi. A typical city guide from 1921, Beautiful Halifax emphasized views, golf courses, and scenic drives around the Bedford Basin's "miles of wooded shores and pretty suburbs" (Figure 5). Although the brochure was presumably aimed at tourists, the Halifax Board of Trade hoped to attract economic interest from other sectors, as it was careful to profile the ocean terminals then under construction as well as the refinery at Imperoyal. ${ }^{14}$ But the cover image of "Canada's Eastern Gateway" showed none of this: only a cluster of schooners sailing off into the sunset, framed by a tall fir 


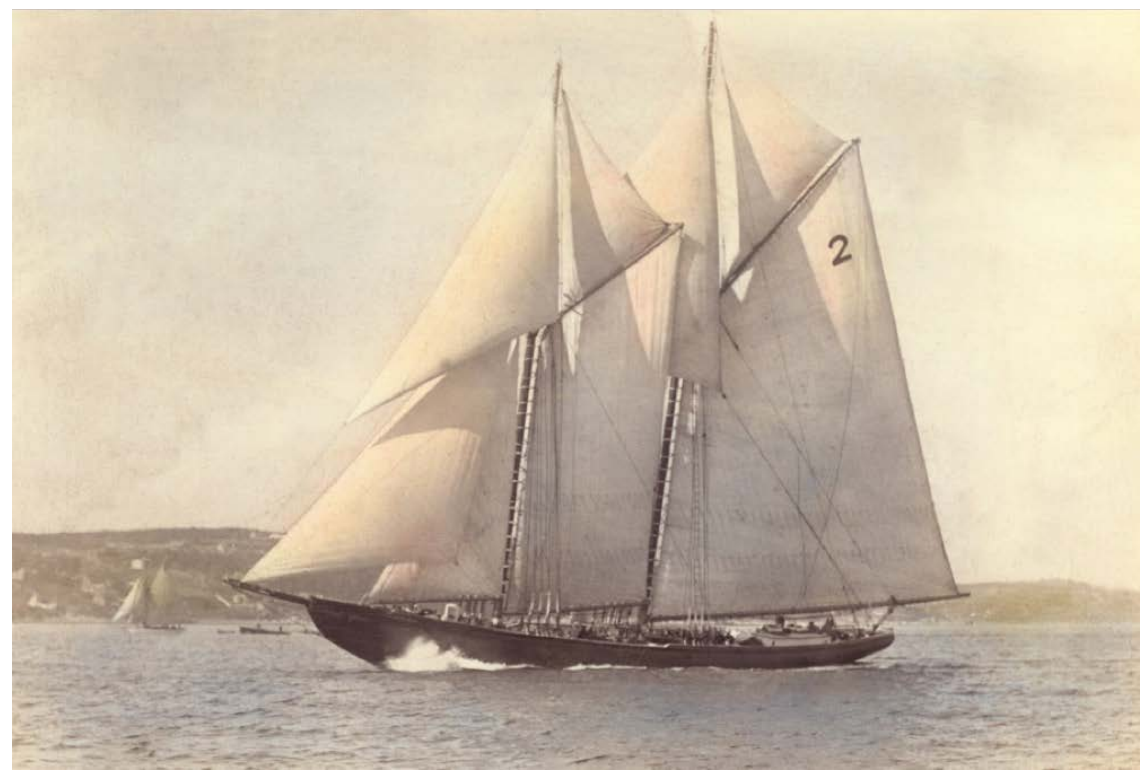

Figure 6. W.A. MacAskill, Bluenose, Halifax Evening Echo, 25 October 1921. NSARM. tree. If the text stressed the modernization of the industrial port, the cover suggested its gentrification or naturalization. It was a tale of two ports.

This was not coincidental. Beautiful Halifax appeared the same year as the single most influential source of sail iconography ever in Canada. The Bluenose was launched in Lunenburg, Nova Scotia, in the spring of 1921 and later that year won the first of several races among schooners vying for the title of fastest in the Grand Banks fishing fleet. Her racing career (and, not to put too fine a point on it, her victories over American schooners) quickly made her an icon in Canada, in circulation on a postage stamp in 1929 and on the dime in 1937. William MacAskill, a Halifax-based photographer, hitched his wagon to the right ship, and his photographs of the Bluenose in motion became and remain highly trafficked (Figure 6). ${ }^{15}$ As a fishing schooner under sail, though, the Bluenose was an anachronism almost as soon as she was launched, since much of the Atlantic fishing fleet was turning to gas and diesel power after the First World War. ${ }^{16}$ Cherished 


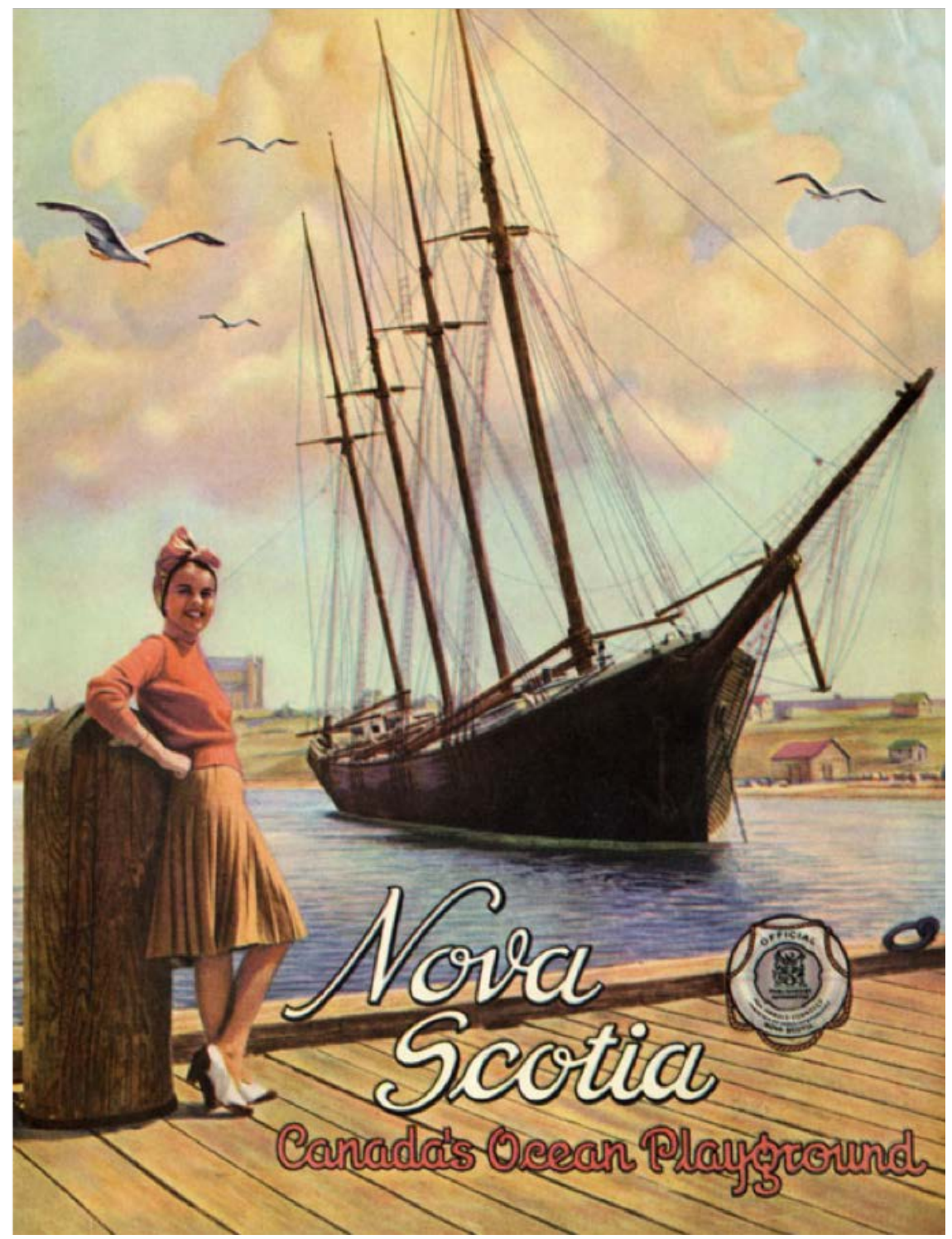

Figure 7. Nova Scotia: Canada's Ocean Playground (1946). N85, F91, N85, NSARM. Inside are more photographs of kerchief-wearing young women, with the explanation, "Sailing ships and pretty girls are Nova Scotia features.” 


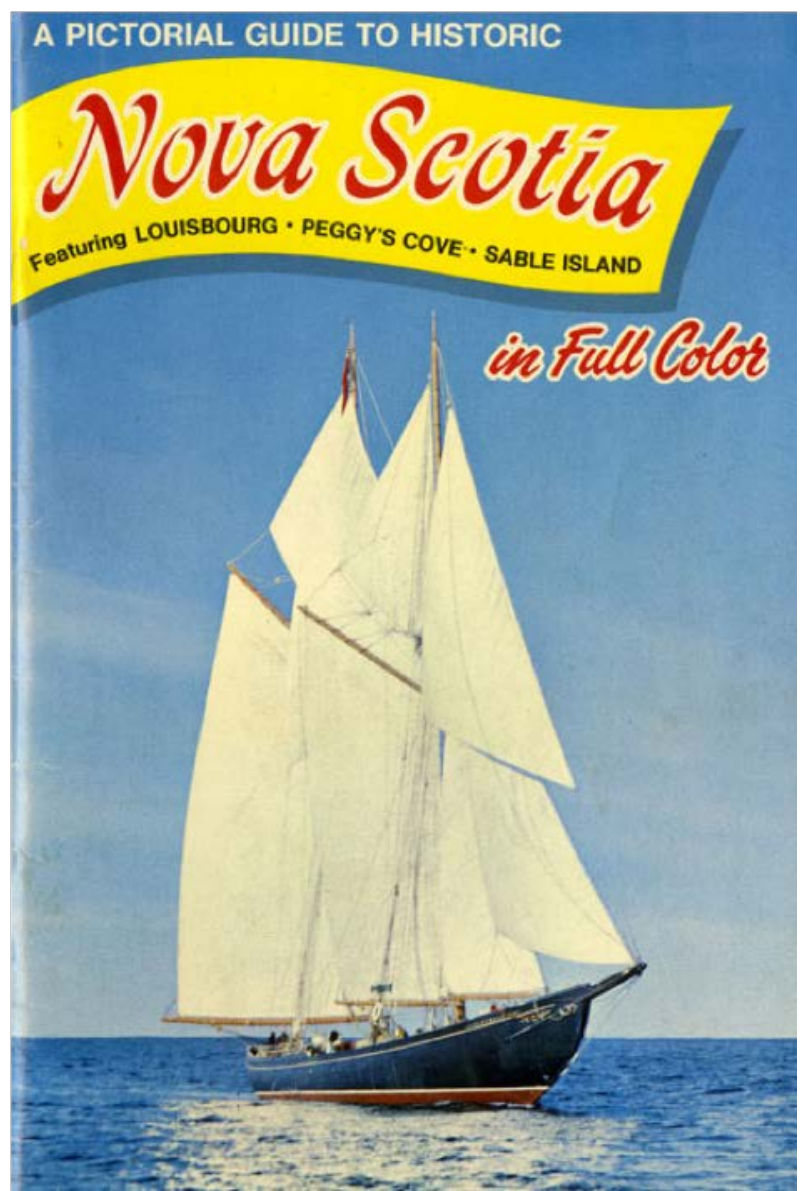

Figure 8. Thomas H. Raddall, A Pictorial Guide to Historic Nova Scotia (1970). No. 3, vol. 309, V/F, NSARM.

for her lines and speed-as something singular, and something to be seenthe Bluenose could appeal to a national audience who had little familiarity with the operation of the Atlantic fishery. But it is worth remembering that this was not the America's Cup: she was raced by working fishers, and she stood for a fleet dedicated to the industrial harvest of the ocean.

Tourism is, of course, itself an industry, and as fishing and mining struggled in the interwar era, tall ships supplied a logical choice for tourism marketing in Nova Scotia. But consider the disjunction in this 1946 edition of Nova Scotia: Canada's Ocean Playground, the annual tourism brochure 


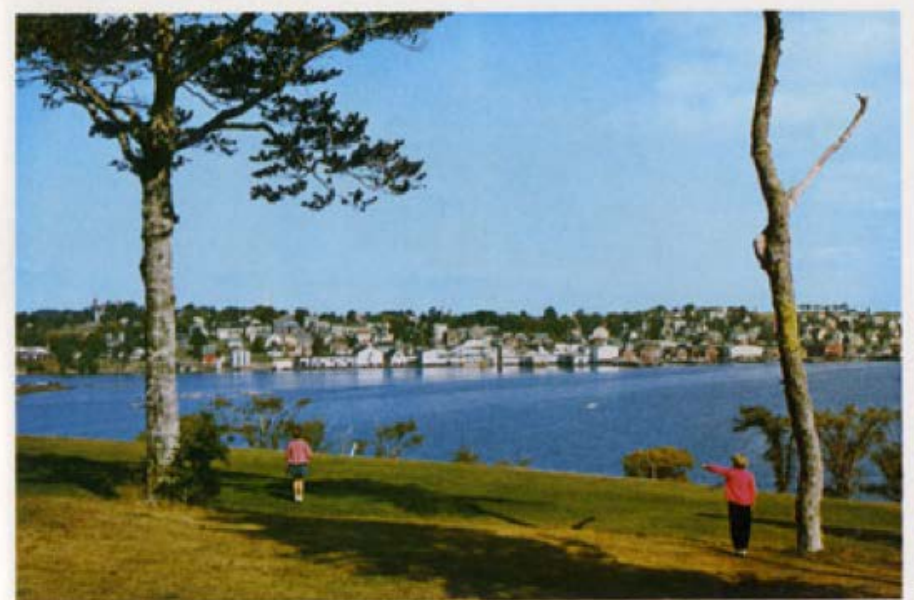

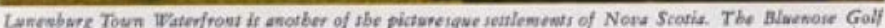

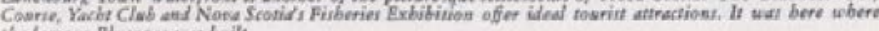
tbe fawowi Blarnove arat betle.

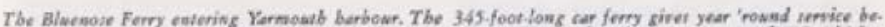

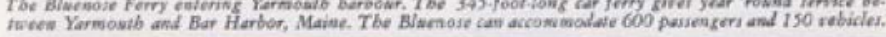

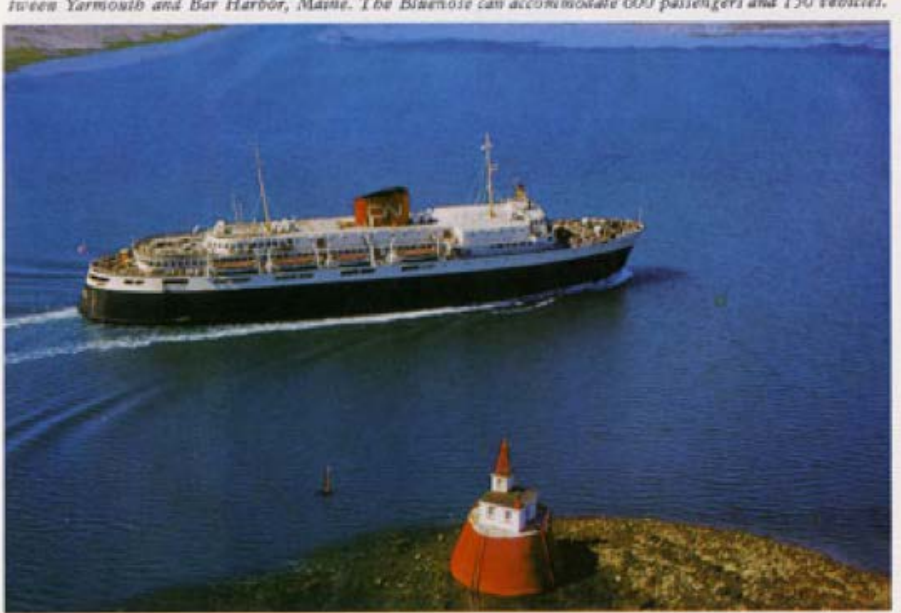

7

Figure 9. Thomas H. Raddall, A Pictorial Guide to Historic Nova Scotia (1970). No. 3, vol. 309, V/F, NSARM. 
that the province had begun to publish twenty years before (Figure 7). Unlike in MacAskill's photographs, the ship here is still, listing, at anchor or perhaps even run aground. ${ }^{17}$ The most impressive display of any sailing ship (with spray and wave, under full sail) is gone; indeed, the foremast is truncated in order to better feature the female model, who poses rather triumphantly on the wharf but with no connection to the ship. (The modelas-tourist-posed, identifiable-is also in sharp contrast with the masculine crews of the working and racing schooners in MacAskill's photographs, often facing away from the camera.) If this was meant to evoke the Bluenose, it was rather cynical; in January of this same year, the Bluenose, working as a cargo freighter, amputated of her masts, had wrecked on Ile à Vache, near Haiti.

A generation later the schooner under sail reappeared on the cover of Canada's Ocean Playground, in motion if not at MacAskillesque speed. Although now it was not the Bluenose but her "namesake daughter," the replica Bluenose II, built in 1963 (Figure 8). ${ }^{18}$ Somewhat paradoxically for a ship invoking a historical icon, the replica becomes oddly timeless in this image; no crew visible, on the open ocean, physically removed from any port of call or its messier politics.

Inside the booklet, however, the ship has vanished altogether, leaving only other namesakes: land-based assets and viewpoints (a golf course looking toward the original slips in Lunenburg), or a massive car ferry designed to carry Americans rather than compete with them (Figure 9). Arguably, this is the most honest representation of postwar tourism in Nova Scotia, with the object of desire and the means of seeing her representing two different modes of propulsion.

In 2007, the annual tourism guide invites us onto the deck of a yacht, a smaller version of the sailing ship, now a marker of personal leisure and private wealth (Figure 10). Here our gaze is narrowed: we are unable to see 


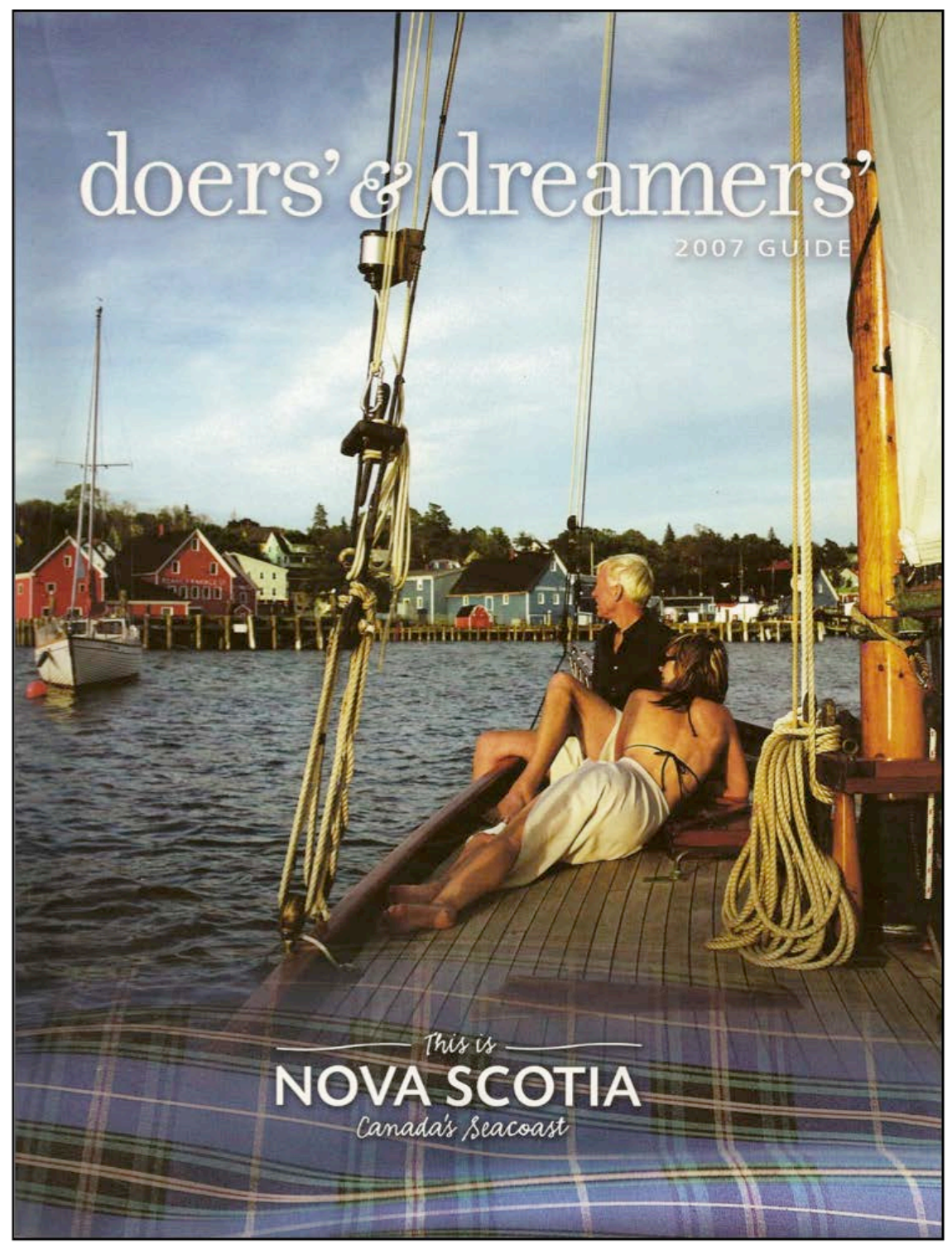

Figure 10. Nova Scotia Tourism, Doers and Dreamers Guide (2007). Province of Nova Scotia. Used with permission. 


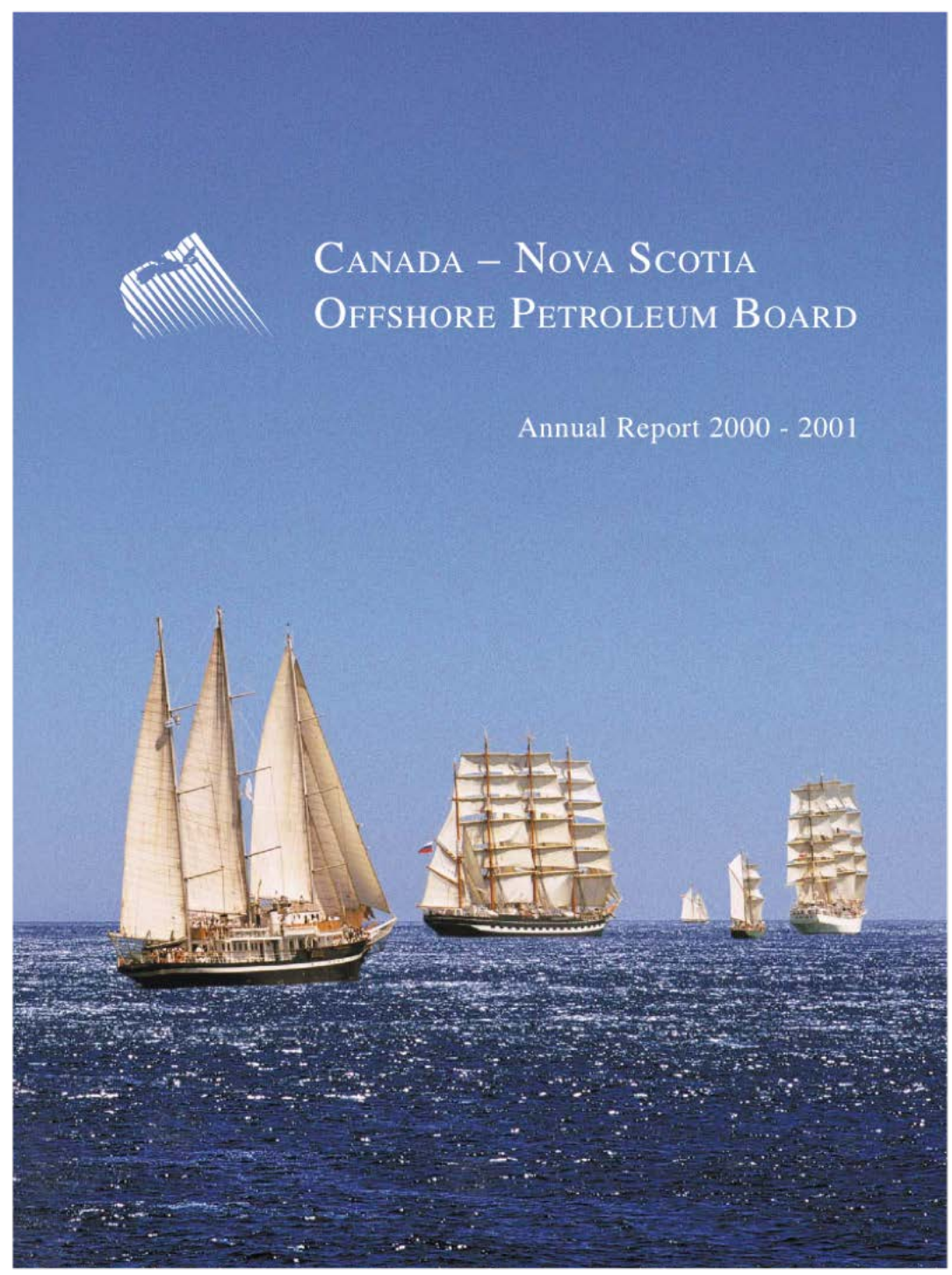

Figure 11. Canada-Nova Scotia Offshore Petroleum Board, Annual Repot 2000-2001. Photograph by Rob Williams.

"Rising with the Tide of History" | 16 
most of the boat and are meant to focus instead on the Lunenburg waterfront beyond, where we are to stroll as tourists (who probably arrived by car). ${ }^{19}$ Whereas in MacAskill's photograph the Bluenose crew is often partly hidden from sight by the sails filled with wind, now the eye goes again, as with the 1946 cover, immediately to the female anatomy, dressed rather inappropriately for any sail in the North Atlantic. This is another reminder that the audience for this version of the sailing ship-whether as icon or recreation-is not the communities that launched or used them.

But the tall ship remains useful as a justification for economic development in ways potentially far more damaging than summer yachting. While it continues to appear in tourism materials in the Maritime provinces, it also has been adopted by or woven into two of the most important industrial and political preoccupations of, specifically, Nova Scotia in the current century: offshore exploration and the national shipbuilding project. In 2001, the Canada-Nova Scotia Offshore Petroleum Board used a photograph of the Tall Ships Regatta departing Halifax, after their visit in July 2000, on the cover of its annual report (Figure 11). Why is this problematic? The CNSOPB was created in 1986 to provide an administrative and fiscal framework to manage offshore development, and "to achieve the early development of Petroleum Resources in the Offshore Area for the benefit of Canada as a whole and Nova Scotia in particular" (essentially ensuring more revenue to Nova Scotia). The CNSOPB, like its sister accord with Newfoundland and Labrador, was an attempt to both avoid repeating past intergovernmental mistakes-the federation had nearly come apart seven years earlier when Alberta swore to "let the eastern bastards freeze in the dark" over a national energy program, and the provinces were increasingly disinclined to let Ottawa monopolize potential revenues-and anticipate the new frontier of offshore resources. 
Despite the collaborative aspirations and language of the accord, the CNSOPB logo betrays the provincial nationalism so profound in Canadian energy politics. The motif swoops from land to sea, driving and divorcing Nova Scotia, already nearly an island, from the rest of Canada, which is otherwise invisible. The province becomes the literal representation of "the offshore state." ${ }^{20}$ But apart from this subtle nod to Nova Scotian empowerment, the cover of the CNSOPB report suggests nothing of complicated and contentious backstory, and nothing of the petroleum frontier at all-except as a frontier. As with its 1921 predecessor Beautiful Halifax, we see the ships-led, significantly, by the comparatively small but confident Bluenose II-departing toward endless possibility. There is no impediment to view, and thus presumably none to development, no unsightly platforms, spills, or fires. Indeed, like MacAskill's photograph of the Bluenose, we have reverted to a view of full sails and no people, open horizons and no histories. By directing our gaze outwards to the oceanic horizon, the photograph reifies the myth of inexhaustibility, while the sparkling waters and clear blue sky suggest purity and a complete lack of any cumulative human impact. The grace of movement literally leaves no footprint. While this may be in keeping with our tendency to think of the ocean as timeless, ${ }^{21}$ it is not a healthy or sustainable fiction.

Furthermore, by substituting the eighteenth-century variant of exploration-especially the impressive square-riggers-as a proxy for offshore drilling, the CNSOPB benefits from heroic associations, with none of the cost or controversy of non-renewable fuels. "Exploration" suggests bravery and the triumph of the human mind and technologies over the unknown of nature.

As a not-so-tangential aside, this is why it translates well into corporate gifts to research and higher education specifically in areas useful for the energy industry. Dalhousie University in Halifax is a case in point. Its 
engineering program was founded in 1907 as the Technical University of Nova Scotia, to provide an educated managerial class for the province's booming coal industry. In recent years, the engineering and earth sciences programs have benefited from donations from Shell Oil and Irving, targeted specifically to studies and internships in subsurface fuel "exploration." Most recently, the two largest research universities in the region (Dalhousie and Memorial University in St. John's) have enthusiastically joined the "Oceans Supercluster," part of an industry-led collaboration designed to make Canada "a global leader in the knowledgebased ocean economy." 22

The original tall ships represented major projects of construction and consumption of both human labour and natural resources. In that sense, they are ideal avatars for offshore development. But the Bluenose and other sailing ships, including her twice-reconstructed namesake, have remained popular and useful because we can separate what they did from how they did it. Beautiful lines and speed suggest human craftsmanship riding the powerful and inexhaustible Atlantic winds, not gruelling and costly traditions of oceanic harvest. ${ }^{23}$ In addition to offering a gloss of romance to extractive industry, these ships-which historically were important tools and displays of state power-remain useful symbols of the territorial (or maritime) reach of state authority.

In its 2001 report, fronted by the tall ships, the CNSOPB touted unprecedented levels of investment in offshore exploration, including a record bid for a single parcel (which has since been dramatically surpassed). Much of this, the board announced, was "in deep water areas where no exploration has taken place in the past," including near Sable Island. Here again we stumble into historical ironies-or fallacies. Sable has been a locus of exploration from the sixteenth century, when its sandbars made it a wellknown hazard to mariners. More to the point, it was also the site of the first 


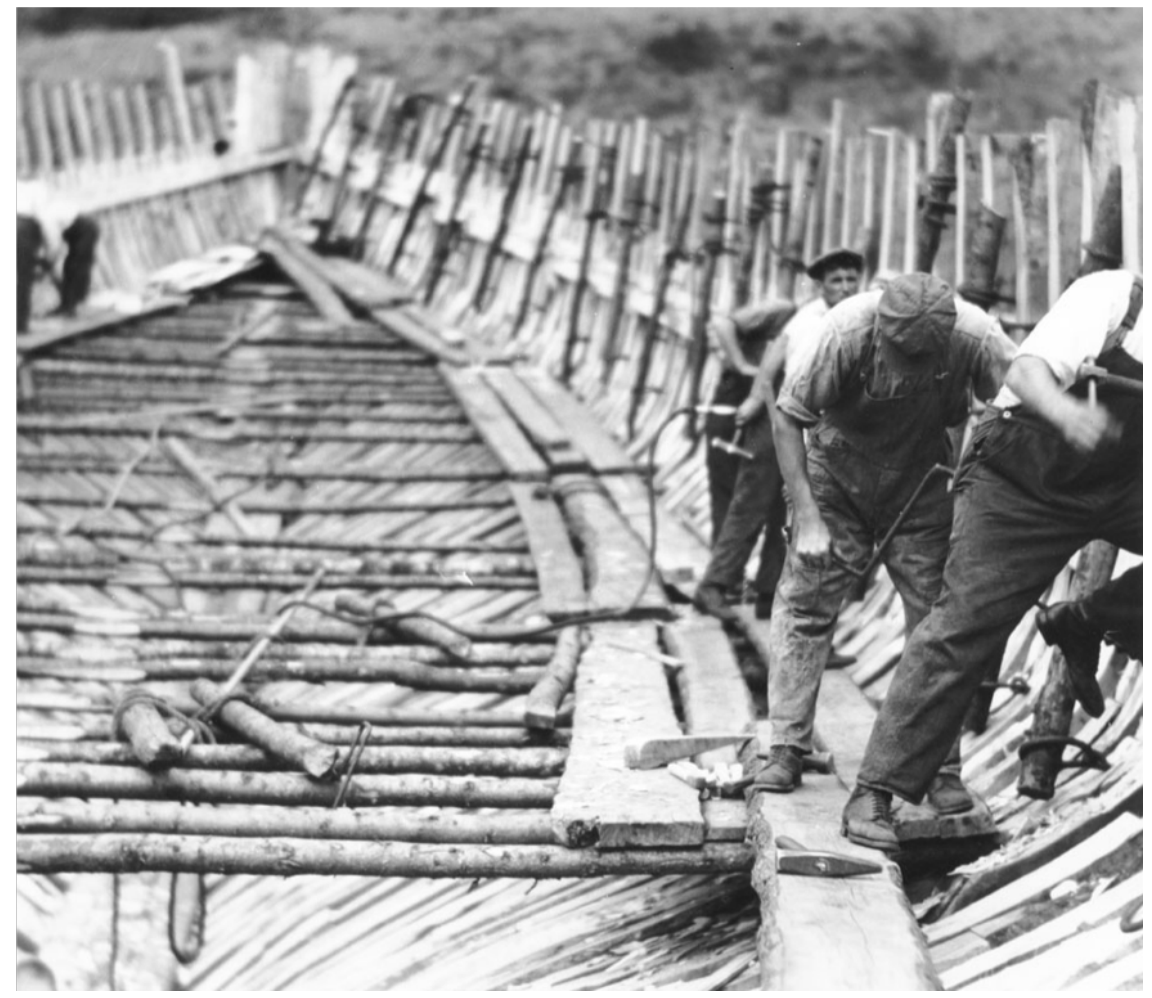

Figure 12. W.A. MacAskill, "Building Bluenose, Smith \& Rhuland's shipyard, Lunenburg" (1920).

offshore projects. Mobil secured exploration permits in 1960 and drilled by $1967 .{ }^{24}$ A highly sensitive sandbar ecosystem, Sable Island was named a national park reserve in 2013. But it now sits in the bull's-eye of ever-larger parcels on the Scotian Shelf as the province has issued leases worth upwards of a billion dollars immediately surrounding the island. ${ }^{25}$ As one reader wrote to the Halifax Herald in 1956, "it must always be remembered, that since Confederation Nova Scotia has had nothing to annex but the sea." ${ }^{26}$ It seems that in the early twenty-first century that is, in fact, exactly what is happening.

And not only by Nova Scotia. In 2010, the federal government announced the National Shipbuilding Procurement Strategy, arguably the most ambitious peacetime naval construction program in Canadian 


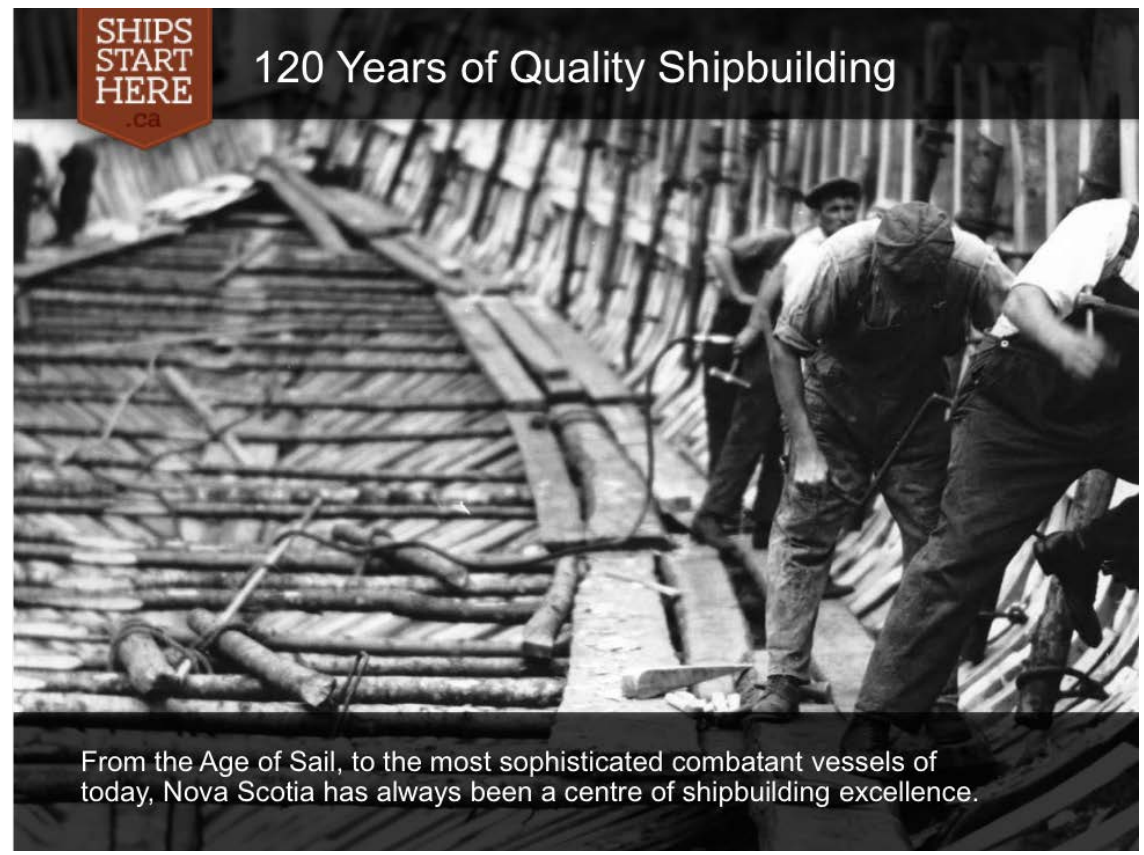

Figure 13. National Public Relations/Halifax Shipyards (Irving), Ships Start Here, 4 May 2011. Used with permission.

history. The first and most coveted component of the program included combat vessels, and offshore and Arctic patrol ships, part of the overt commitment to Arctic sovereignty under Stephen Harper's Conservative government. Irving Shipbuilding of Saint John, New Brunswick-which had purchased the Halifax Shipyard in 1994-bid for the combat contract with the financial support of the province of Nova Scotia. Irving enlisted the Halifax office of a national public relations firm to cultivate local support for the bid. ${ }^{27}$ The PR campaign, titled "Ships Start Here," characterized Nova Scotians as natural shipbuilders by assembling a genealogy that ran from Samuel Cunard to the Halifax Shipyard, suggesting that the anticipated patrol fleet belonged in Halifax from conception to launch. But it also capitalized on an assumed nationwide familiarity with shipbuilding, and specifically one ship, as Nova Scotian. 
The campaign used archival photographs of the Halifax Shipyard, and an iconic aerial photograph of a 1942 convoy in the Bedford Basin during the Battle of the Atlantic. In rather more of a stretch, "Ships Start Here" also featured a 1920 photograph by W.A. MacAskill, of the Bluenose under construction at Lunenburg (Figures 12 and 13). The Lunenburg shipyard (although it still exists) was not "here," at least for the purposes of the bid, while the Halifax Shipyard is the largest shipyard in eastern Canada. So why include a photograph from Lunenburg? Obviously, it referenced the most famous ship ever built in Nova Scotia and claimed it in a tradition of shipbuilding in national service (indeed, the Bluenose did double duty here, appearing as the dime in another image from the same campaign). "Ships Start Here" thus courted local favour by insisting on Nova Scotia's shipbuilding as more legitimate than the claims of its competitors in Vancouver and Quebec City: bigger cities with economic eggs in comparatively more baskets, and at greater geographic distance from the subject seas (the eastern Arctic). But why include a schooner in what became a $\$ 3.5$ billion contract for top-of-the-line diesel patrol and combat vessels?

Besides the appeal to regional pride and exceptionalism, suggesting a particular affinity with ships and the sea, ${ }^{28}$ there is a call to artisanship, an ostensibly pre-industrial craftsmanship, with men working with hand tools in a wooden cradle. But there is a disingenuous quality to the use of the Bluenose here, in that, like the CNSOPB report, invoking the power of wind and sail is an allusion to a more sustainable and more publicly palatable form of energy. In fact, the contracted frigates are a perfect symbol of the Anthropocene: a nexus of industrial construction, state sovereignty, and fossil fuel consumption ... fossil fuels, it has to be said, that the Navy's ships occasionally spill in the harbours that launch those ships. ${ }^{29}$ Halifax has long thought of itself as the "warden of the north," a "garrison 


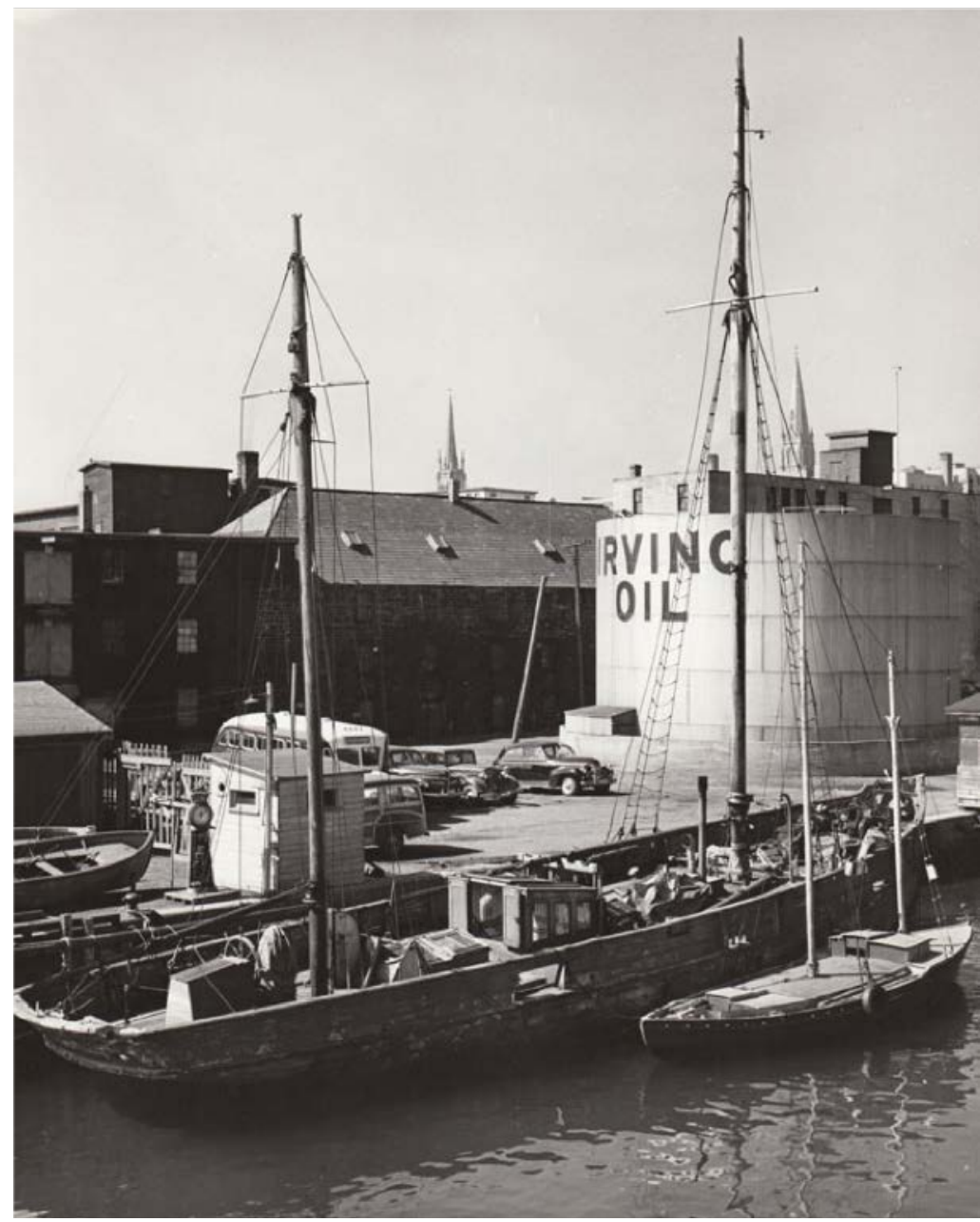

Figure 14. Schooner at Irving Oil (Sackville) Wharf, undated. NSIS 2420, NSARM. city," a bulwark against incursion. But even in a province and city deeply invested in the history, economy, and employment of the armed forces, a tall ship is a kinder, gentler demonstration of maritime authority than a destroyer.

The move toward offshore in the late 1970s confirmed Halifax as "the first city of East Coast exploration." ${ }^{30}$ But as we have seen, it had been a major fuel depot since the mid-nineteenth century. The Dockyard served as a coaling station for the North American squadron of the Royal Navy, 


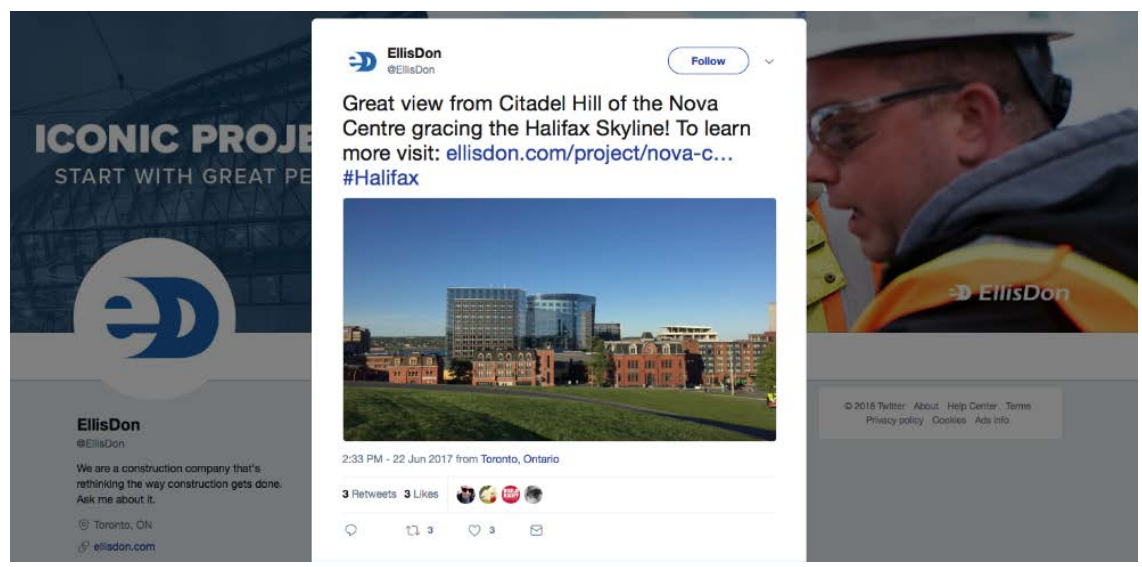

Figure 15. The Nova Centre announced by EllisDon, 22 June 2017. Used with permission. the Intercolonial Railway delivered coal from Pictou and Cumberland counties, and later, offices for coal and oil companies lined Lower Water Street. ${ }^{31}$ And suddenly it does become a very Canadian story, where ideas of sovereignty-whether in national defence or national wealth-have been entwined with fossil fuels. Figure 14, a photograph by the Nova Scotia Information Service, the agency responsible for marketing the province since 1924, conveys a working waterfront by featuring its two most prominent industries. But compared to the age of sail, there is little public memory or presence of this history, perhaps because it is at once too valuable, too current, and too removed. One the one hand, as Carola Hein as shown, port sites of the global "petroleumscape" are generally too deeply entrenched to be easily dislodged. ${ }^{32}$ Yet, as with the Dockyard and other military properties, fenced off to civilians, most of us will only glimpse refineries and tankers from across the harbour. Offshore is invisible, except when rigs are pulled in for repair. The wharf where the Irving tank sat as late as 1982 now hosts a provincial visitors centre-and the tall ships, when they come to port. ${ }^{33}$

Instead, new developments use seafaring motifs in architecture to legitimize their presence in a city that was never intended for projects of such purpose or scale. The controversial Nova Centre (whose developers 


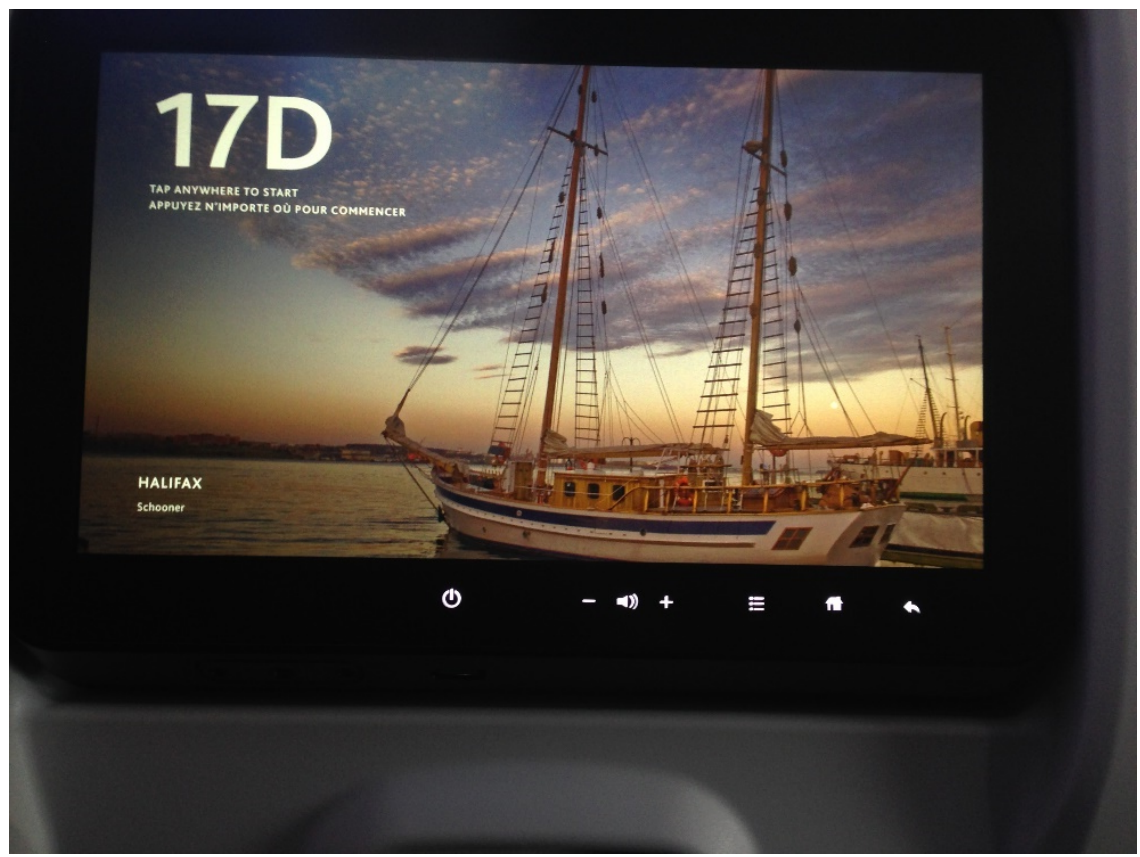

Figure 16. Air Canada Flight 628, Toronto to Halifax, 3 May 2018. Photograph by Tina Loo.

also stressed their local roots) was designed to resemble a prow arriving in Halifax Harbour, in both shape and colouring. ${ }^{34}$ As at Queen's Marque, however, there are a few ironies it is impossible not to trip over en route to an imaginative revisiting of the past. The most prominent is that the Nova Centre blocks the view from the Halifax Citadel to the harbour more than any other construction in the downtown (Figure 15). In 1974 Halifax City Council adopted a bylaw that identified ten crucial "view planes"-sight lines from Citadel Hill to different points around the harbour that had been necessary to communicate with ships-as a way to protect its intangible heritage: a distinct sense of place and a reminder of the city's founding raison d'être. The Nova Centre is not the only project (both before and since 1974) to protrude into the view planes, but it is the bulkiest.

Whereas the Halifax waterfront in the age of sail was crowded with wharves and ships designed to slide tightly together to resemble a forest of 


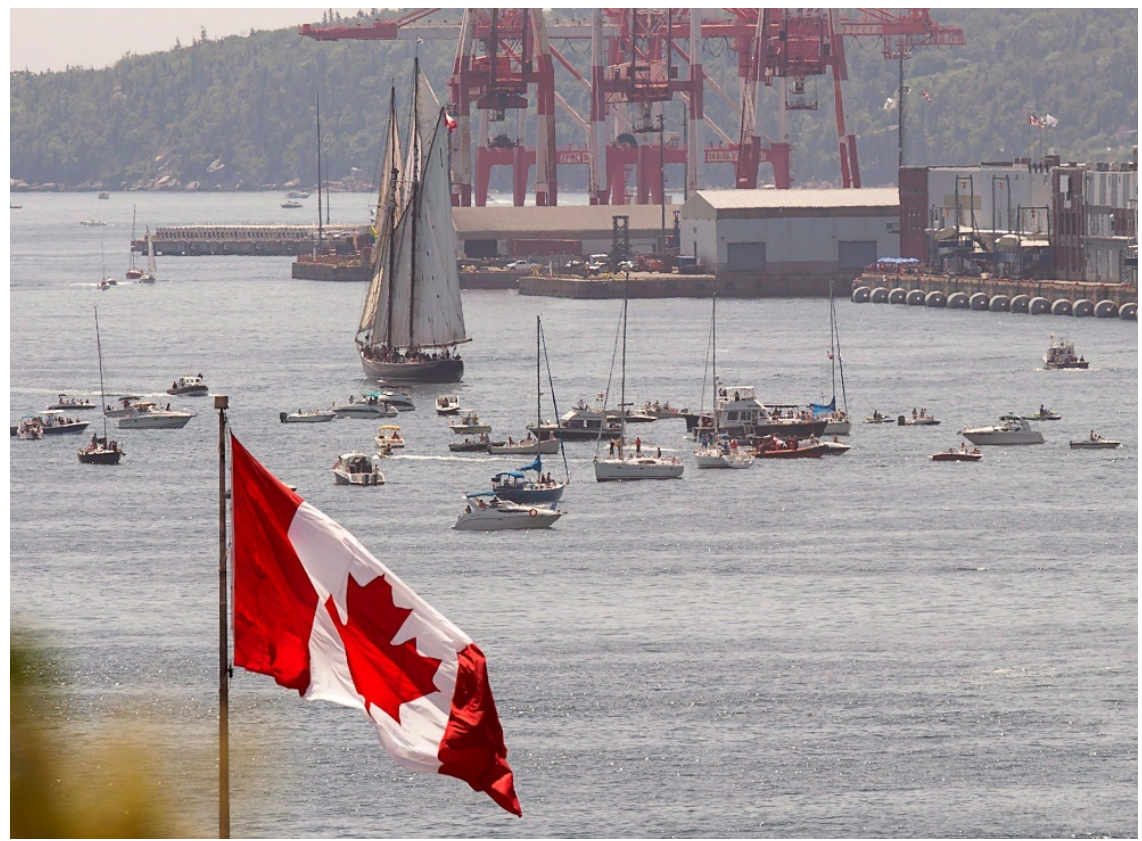

Figure 17. Bluenose II, Nova Scotia's sailing icon, participates in a parade of sails as part of

Rendezvous 2017 in Halifax on 1 August 2017. Canadian Press/Andrew Vaughan. spars (a common expression of the day), the heavy mass of contemporary projects such as the Nova Centre and Queen's Marque occupy space in a much more singular, enclosed fashion. Indeed, despite allusions to nineteenth-century sail, these are more closely aligned with a twentiethcentury tradition of infill remaking the waterfront for load-bearing bulk. ${ }^{35}$

While contemporary architecture pushes forward under a motif of sail, Nova Scotia also continues to market itself as a place where the historical age of sail is still alive. The province has invested deeply in marketing its past since the late nineteenth century. Seen through the lens of energy history, this story takes on a new poignancy. ${ }^{36}$ Tourists are invited, as they have been for over a century, to travel to the coast; to do so necessarily by consuming fossil fuels, once coal (steamer and rail), then petroleum (cars, now airplanes, as with a soothing back-of-the-seat image-figure 16designed to ameliorate the unpleasant experience of air travel). Yet they are

"Rising with the Tide of History" 26 
promised-and come intent on seeing-a place that somehow exists outside the age of carbon, even as those small coastal communities are increasingly vulnerable to storm surge and sea-level rise attributed to the climate change caused by the consumption of fossil fuels. ${ }^{37}$

The age of sail draws a veil over industrial realities, past and present. Consider, finally, this photojournalistic view of the Parade of Sail (Figure 17), the traditional closing to a tall ships visit as they prepare to leave port. Our eyes are drawn to the Bluenose II in the centre of the photograph, the hometown hero granted pride of place in the line, the final ship to sail past the Halifax waterfront. Yachts cluster like goslings in her wake. This grouping, this visual genealogy, suggests that ships do start here, that Nova Scotians remain a people of the sea, their sailing skills not lost, even if the yacht owners are a well-to-do, urban group that spends most of their days on land (and in SUVs).

More importantly, by focusing (both the camera lens and our own gaze) on the Bluenose II and her progeny-and the Canadian flag in the foreground-we forget to look at the industrial port behind them, truncated and blurred. The construction of the Ocean Terminals during and after the First World War was a massive undertaking, an enormous reshaping of granite peninsula and harbour shoreline to facilitate industrial traffic. A half-century later, the port lands were extended again with a new container terminal. These yachts are sailing past what was once a road to Point Pleasant Park, a neighbourhood called Greenbank, ponds and freshwater streams, and ironically, the Royal Nova Scotia Yacht Squadron clubhouse probably with no sense of what lies underneath the container port. ${ }^{38}$ The sailing ships help block the view and acknowledgement of our own industrial landscape.

The entrenched patterns and pursuit of industrial capital that still govern Atlantic shorelines are themselves as Canadian as the dime. But the 
age of sail need not be merely an alibi for other kinds of economic development; it could be a signpost, an inspiration, if read literally. As Eric Sager has said so well, "The cost of every dollar invested in petroleum is the foregone opportunity of investment in another energy source. ${ }^{39}$ Instead of using the age of sail to authorize fossil fuels, why not embrace the power of wind and tide on their own terms? If Nova Scotia believes itself to be shaped by the sea, would it not make more sense to think and act more like a North Atlantic state than a North American one, like other smaller coastal jurisdictions rather than large terrestrial ones? It might find a better model in places like Denmark: another historic seagoing power that now leads the European Union in wind power and the world in turbine technology. What if we were to see the schooners in the Nova Scotian cradles as the nineteenth-century kin of turbines: projects of substantial construction that require technological expertise, a crucial means to participate in international markets, and a way to distinguish the small peninsula from the larger continent? ${ }^{40}$ It is a question of which version of the nineteenth century we wish to take inspiration from: the age of sail or the turn to fossil fuels. Historians are often wary of predicting the future, but all signs point to the tide rising with only one of them.

${ }^{1}$ For its part, King's Wharf offers buyers the chance to make one of their condominiums "your home port." Language taken from www.queensmarque.com and www.kingswharf.ca. My thanks to the reviewers of the manuscript, Sean Kheraj and the editors of PiCHE, and to participants of the 2018 Northeast \& Atlantic Region Environmental History workshop, especially Matthew McKenzie, who offered feedback on an earlier draft. I am also grateful to the wonderful staff at the Nova Scotia Archives and Acadia University Archives for their help with images, and to Tina Loo for the use of her photograph. ${ }^{2}$ Turbines installed in 2009 were pulled out the next year after significant damage. A stronger prototype was installed in 2016 and removed in 2017 for 
further modifications. "Giant Turbine Placed on Seabed to Harness Powerful Bay of Fundy Tides," Halifax Chronicle Herald, 7 November 2016; Michael MacDonald, "Environmental Impact of N.S. Turbines Must Be Researched: Executive Director," CTV News, 16 January 2018, https://www.ctvnews.ca/canada/environmental-impact-of-n-s-turbines-mustbe-researched-executive-director-1.3762067. In January 2018 the province issued a call for small-scale test projects. Although historically concerns with the tidal power of the Bay of Fundy were related primarily to navigation and shipping, interest in tidal generation date to at least the First World War: see "Power from Tidal Currents in Bay of Fundy," Journal of the Royal Society of Arts 64, no. 3333 (1916): 788.

${ }^{3}$ Matthew McClearn, "Halifax's Battle of the Rising Sea: Will the City Be Ready for Future Floods and Storms?” Globe and Mail, 5 March 2018, https://www.theglobeandmail.com/news/national/rising-sea-levelshalifax/article38160929/.

${ }^{4}$ Michael Gorman, "Premier to Lead N.S. Group at Offshore Conference in Texas," CBC News, 27 April 2018, http://www.cbc.ca/news/canada/novascotia/stephen-mcneil-offshore-energy-oil-drilling-gas-lng-texas-1.4637555; "N.S. Premier to Pitch Federal Panel on Offshore Oil, Gas Exploration," Chronicle-Herald/Canadian Press, 3 May 2018. See also Claire Campbell, "Privileges and Entanglements: Lessons from History for Nova Scotia's Politics of Energy," Acadiensis 42, no. 2 (2013): 114-37. The great irony is that after fifty years of exploration, the "Scotian Basin remains an 'almost resource," regardless of the ebbs and flows of capital investment or government interest. See Peter Clancy, Offshore Petroleum Politics: Regulation and Risk in the Scotian Basin (Vancouver: University of British Columbia Press, 2011), 144. Yet fossil-fuel hope, however ill-informed by history, springs eternal; in June 2018 the province announced another $\$ 12$ billion for offshore research, followed two days later by news of a spill of "drilling mud" by a British Petroleum rig located 330 kilometres from Halifax. Nova Scotia Department of Energy, "Government Investing More in Offshore Research," news release, 20 June 2018, https://novascotia.ca/news/release/?id=20180620003; Danielle d'Entremont, 
“BP Reports Drilling Mud Spill off Nova Scotia,” CBC News, 22 June 2018, http://www.cbc.ca/news/canada/nova-scotia/bp-spill-offshore-nova-scotia1.4718942.

${ }^{5}$ Statistics Canada, World Water Day, 2017/Canada Year Book(2012), https://www.statcan.gc.ca/eng/dai/smr08/2017/smr08_215_2017. Scholars such as Sara Spike and Kate Bauer (in Canada) and Christopher Pastore and Kara Schlichting (in the United States) promise to expand our understanding of coastal history as environmental history.

${ }^{6}$ Arthur Lower, Unconventional Voyages (Toronto: Ryerson, 1953), viii-ix. ${ }^{7}$ A rhizome is a kind of plant stem that sends out roots (or rootstalks) from underground nodes. (Consider ginger.) Separate parts of the rhizomic plant can form new plants. This image of horizontal creeping and persistent reproduction lends itself to metaphor; for example, NiCHE has a series called "Rhizomes" dedicated to profiling the work environmental history graduates who work outside the academy.

${ }^{8}$ One interesting attempt to acknowledge the weight and limitations of this history-in political as well as environmental terms - is the collection of essays in John Reid and David Savoie, eds., Shaping an Agenda for Atlantic Canada (Halifax: Fernwood Publishing, 2011).

${ }^{9}$ Peter McLaren MacDonald, Letters from the Canadian West (Truro: n.p., 1903), 53-4.

${ }^{10}$ On the coal industry, see the work by David Frank, Ian McKay, Steven Penfold, and Lachlan Mackinnon. It's telling that Nova Scotia features far more prominently in the chapter on coal energy than that on wind power in Ruth Sandwell, ed., Powering Up Canada: The History of Power, Fuel, and Energy from 1600 (Montreal and Kingston: McGill-Queen's University Press, 2016).

${ }^{11}$ The environmental history of the ocean terminals has yet to be told, but by way of introduction, see Frederick Cowie, Report to the Honourable Frank Cochrane, Minister of Railways and Canals, on Halifax Harbour and the Development of a Project of Modern Ocean Terminals (Montreal: n.p., 1913). J.D. Frost, "Halifax: The Wharf of the Dominion, 1867-1914," Journal of the Royal Nova Scotia Historical Society, 8 (2005): 35-48; and James Frost, Canada's Atlantic Gateway: 
An Illustrated History of the Port of Halifax (Halifax: Nimbus, 2008). Historians Steven Schwinghamer and Monica MacDonald of Pier 21 National Historic Site are working on a built history of the piers and surrounding area.

${ }^{12}$ See Steven Gray, Steam Power and Sea Power: Coal, the Royal Navy, and the British Empire, ca. 1870-1914(London: Palgrave Macmillan, 2018), https://doi.org/10.1057/978-1-137-57642-2.

${ }^{13}$ McAlpine Halifax City Directory (Halifax, 1916), Nova Scotia Archives \& Records Management (NSARM).

${ }^{14}$ Halifax Board of Trade, Beautiful Halifax: The City by the Sea (1921), 7, 9. Imperial Oil would "MAKE HALIFAX THE GREATEST OIL DISTRIBUTING POINT ON THE NORTH ATLANTIC COAST," said the Halifax Herald with some enthusiasm in 1917. "The Tremendous Works on Halifax Harbour," Halifax Herald, 31 December 1917, 23. All-caps in the original.

${ }^{15}$ See W. A. MacAskill, Out of Halifax: A Collection of Sea Pictures (New York: Derrydale Press, 1937), which is a combination of tranquil photographs of fishing villages and dynamic moments with the fishing fleet in sail. On the races of the period, see M.W. Santos, Caught in Irons: North Atlantic Fishermen in the Last Days of Sail (Selinsgrove, PA: Susquehanna University Press, 2002).

${ }^{16}$ Edward MacDonald and Boyde Beck, "Time and a Place in a Fishery," Time and a Place: An Environmental History of Prince Edward Island (Montreal and Kingston: McGill-Queen's Press, 2016), 231-3; Santos, Caught in Irons, 21. As Santos explains, by the time of the international series that made Bluenose famous, most racing was (paid) for (by) yachtsmen-investors living vicariously through the fishing crews. And in an era of prohibition, a substantial portion of the Lunenburg fleet was being sold into the rum-running trade (75). The anachronistic nature of the Bluenose is underscored by the name of her rival in the 1922 race: the Henry Ford.

${ }^{17}$ I owe this reading of the ship to Matthew McKenzie, who touches on the way in which coastal fisheries were framed (or erased) in order to no longer be in competition with the new industry of tourism: see Clearing the Coastline: The Ecological and Cultural Transformation of Cape Cod (Lebanon, NH: University Press of New England, 2010). On this era of tourism in Nova Scotia, see Sarah 
Osborne, "The Road to Yesterday: Nova Scotia's Tourism Landscape and the Automobile Age, 1920-1940,” M.A. thesis, Dalhousie University, 2009. On the basis of other photographs in the 1946 brochure, the cover photograph, while not identified, was likely taken at Digby.

${ }^{18}$ Stan Rogers, "Bluenose," Turnaround(1978). See Cheryl Sullivan, “The Paradox of Bluenose II: Antimodernism, Capitalism, and the Legacy of the Schooner Bluenose in Nova Scotia," Nova Scotia Historical Review 16, no. 2 (1996): 1-22. The Bluenose II was sponsored by Oland's Brewery, and sold to the province for one dollar in 1971 as a "sailing ambassador." Repair from 2009 through 2016 proved both expensive and controversial, raising questions of whether she now exists as a Bluenose III, and if so, what her relationship with the original may be.

There is an interesting analogy with the Wanderer-the last square-rigged whaler built in 1898 in Mattapoisett, Massachusetts, featured in the 1922 film Down to the Sea in Ships (a film sponsored by the Whalemen's Association of New Bedford). Ironically, the Wandererwrecked shortly thereafter, but as Bruce Robertson notes, "As an image, the Wanderer, existing as an artifact only in memory, still manages to reach every kind of mass-market audience, from the most elite to the broadest and most popular." "Perils of the Sea," in Picturing Old New England: Image and Memory, ed. William H. Truettner and Roger B. Stein (New Haven, CT: National Museum of American Art/Yale University Press, 1999), 167.

${ }^{19}$ Claire Campbell, "Global Expectations, Local Pressures: Some Dilemmas of a World Heritage Site," Journal of the Royal Nova Scotia Historical Society 11, no. 1 (2008): 69-88.

${ }^{20}$ Canada-Nova Scotia Offshore Petroleum Resources Accord, August 26, 1986. This was formalized in 1988 as Canada-Nova Scotia Offshore Petroleum Resources Accord Implementation Act (or, An Act to Implement an Agreement between the Government of Canada and the Government of Nova Scotia on Offshore Petroleum Resource Management and Revenue Sharing and to Make Related and Consequential Amendments). See Douglas Day, "Maritime Boundaries, Jurisdictional Disputes, and Offshore Hydrocarbon Exploration in Eastern Canada," Journal of Canadian studies/Revue d'études canadiennes 23, no. 
3 (1988): 60-89, https://doi.org/10.3138/jcs.23.3.60; and Clancy, Offshore Petroleum Politics. In the tumultuous and uncertain energy landscape of the 1970s, offshore resources became a new focus in federal policy in 1976, but in the wake of Alberta's vaulting into oil wealth and the National Energy Policy, much of the momentum was driven by ambitions of provincial sovereignty. According to the British North America Act (1867), Canada's founding constitutional document, the provinces are responsible for-and thus entitled to revenues from-"The management and Sale of the Public Lands belonging to the Province and of the Timber and Wood thereon," a phrase that was extended to mineral revenue almost immediately. The same act, however, also allocates "The Sea Coast" to the federal government. When patriated as the Constitution Act in 1982, provincial jurisdiction (and taxation authority) over "Non-Renewable Natural Resources, Forestry Resources and Electrical Energy” was separated out and underscored in its own section (92a).

${ }^{21}$ W. Jeffery Bolster, "Putting the Ocean in Atlantic History: Maritime Communities and Marine Ecology in the Northwest Atlantic, 1500-1800," American Historical Review 113 (2008): 19-47, https://doi.org/10.1086/ahr.113.1.19; and W. Jeffery Bolster, "Opportunities in Marine Environmental History," in Global Environmental History: An introductory reader, ed. J.R. McNeill and Alan Roe, 53-81 (New York: Routledge, 2013).

${ }^{22}$ See “Canada's Ocean Supercluster," https://oceansupercluster.ca. The donations have caused some controversy over the appropriateness of corporate logos and involvement in academic projects. To be fair, though, neither Dalhousie nor Memorial is unusual among universities in accepting large gifts from oil and gas companies!

${ }^{23}$ Glenn M. Grasso makes the salient point that even the term harvest has the effect of romanticizing this industry: "Commercial fishing is sometimes colloquially called 'harvesting the sea,' invoking quiet images of a preindustrial, pastoral labour ripe with the Protestant work ethic. Harvesting is a misnomerthe image false-because harvesting implies cultivating. Fishing should more accurately be termed mining; indeed the closest analogy for an industry 
extracting what is already there." "Escaping the Maritime Revival Viewpoint," in Fluid Frontiers: New Currents in Marine Environmental History, ed. John Gillis and Franziska Torma (Winwick, UK: White Horse Press, 2015), 40.

${ }^{24}$ Clancy, Offshore Petroleum Politics, 61. In another irony/coincidence, the Gloucester schooner that won the first International Fishing Vessel Championship in 1920-prompting the retaliatory construction of the Bluenose that winter-wrecked on Sable the next year. Santos, Caught in Irons, 85.

${ }^{25}$ Energy Nova Scotia, "Nova Scotia Petroleum Rights (Including Forecasted Call Areas)," 2018,

https://energy.novascotia.ca/sites/default/files/files/Offshore_Rights_including _Forecasted_Areas.jpg; and CNSOPB, “CNSOPB Call for Bids Forecast Areas,” https://www.cnsopb.ns.ca/lands-management/call-bids-forecast-areas ${ }^{26}$ F.A Lewis, letter to the editor, Halifax Herald, 12 December 1956.

${ }^{27}$ National Public Relations, http://redcouch.ca/portfolio/ships-start-here/; “Shipbuilding PR Campaign Untendered,” Chronicle Herald, 28 February 2012. The archival images used can be found at https://www.flickr.com/photos/shipsstarthere/with/5665650962/, with the text to accompany them (especially the Halifax shipyard, and the Smith and Rhuland dock) at the images. It also invited a few parodies, including "Starships start here," in which people Photoshopped images from Star Wars onto the campaign's posters and other images of Halifax. As further illustration of the argument about the relationship between higher education and industrial (specifically fossil fuel) operation, Irving also created an Irving Shipbuilding Research Chair in Marine Engineering and Autonomous Systems at Dalhousie in 2018.In this, neither Irving nor Dalhousie is in any way unusual, but rather, representative. ${ }^{28}$ Lesley Choyce, Nova Scotia: Shaped by the Sea (Halifax: Nimbus, 2007). ${ }^{29}$ To be fair, the spills are relatively infrequent, given the amount of shipping traffic (and the most recent spill, in August 2018, was the fault of Nova Scotia Power), but we should also recognize the cumulative effect over nearly two centuries. Tim Krochak, "Canadian Warship Spills Diesel into Halifax harbour," Globe and Mail, 8 May 2013, https://www.theglobeandmail.com/news/national/canadian-navy-warship- 
spills-diesel-into-halifax-harbour/article11787732/. A more recent spill took place near Canada's other major naval base, in Esquimault, British Columbia. Chad Pawson, "Canadian Navy Ships Spills 30,000 Litres of Fuel into Strait of Georgia," CBC News, 25 February 2018, http://www.cbc.ca/news/canada/british-columbia/hmcs-calgary-fuel-spill1.4551467. In a wonderfully if wincingly cyclical story, the barge used to pump up some of the fuel from one of Canada's worst coastal oil spills (the S.S. Arrow, 1970, off Chedabucto Bay) was the Irving Whale. The Whale sank with a full load of fuel in the Gulf of St. Lawrence six months-and sat on the bottom for twentysix years. Recovered in 1996, she is now shuttling materials across the Halifax harbour to the Irving shipyard as part of the patrol vessel project.

${ }^{30}$ Clancy, Offshore Petroleum Politics, 84.

${ }^{31}$ The U.S. Navy noted that coal staithes at Halifax could drop ninety tons an hour, along with the convenience of an ice-free harbour, in Coaling, Docking, and Repairing Facilities of the Ports of the World, with Analyses of Different Kinds of Coal, 3rd ed. (1892), 16-17 (although this still rated as "slow"). City directories are an excellent guide to the commercial waterfront.

${ }^{32}$ Carola Hein, "'Old Refineries Rarely Die': Port City Refineries as Key Nodes in the Global Petroleumscape," Canadian Journal of History/Annales canadiennes d'histoire 53, no. 3 (2018): 450-79, https://doi.org/10.3138/cjh.ach.53.3.05. For all the commercial (let alone public) value of water frontage, one of the most striking qualities of the Halifax Harbour is the amount of real estate owned by the Department of Defence. John Tunbridge makes the point that the possible uses of naval heritage are limited where-as in the case of Halifax-bases are still in use by national navies. See "Naval Heritage and Postcolonial Geography: Why It Should Matter to Australia," Geographical Research 49, no. 1 (2011): 86-98, https://doi.org/10.1111/j.1745-5871.2010.00668.x.

${ }^{33}$ Irving was a relative latecomer to the downtown harbour (1936), but remained the most prominent reminder of the fuel history with tanks until 1982 (email communication with Carolyn Gilbert, Waterfront Development Corporation, 25 May 2018). Sackville Landing is now home to a provincial tourism visitors bureau, a playground, the Maritime Museum of the Atlantic, the historic HMCS 
Sackville, various memorials, and The Wave, a sculpture by Donna Hiebert. The facade of the Imperial Oil building was kept in the 2012 "Waterside Centre," by the same group behind Queen's Marque.

${ }^{34} \mathrm{See}$ https://novacentre.ca/about/nova-centre.

${ }^{35}$ Bob Chaulk, Time in a Bottle: Historic Halifax Harbour from the Bottom Up (Lawrencetown Beach, N.S.: Pottersfield, 2002), gives the diver's perspective on the concrete wharves built for ever-larger military, commercial, and cruise vessels. The view plane question is long, contentious, and entangled with current municipal politics and planning debates, but dates to 1974. The views are, technically, still protected by the city's bylaws, although exemptions are allowedas with the Nova Centre. See View Plane Requirements S. 14-16 and Rampart Requirement S. 17. https://www.halifax.ca/sites/default/files/documents/aboutthe-city/regional-communityplanning/PEN\%20223_Effective_June\%2017\%202017.pdf. See Jill L. Grant and Gladys Wai Kwan Leung, "Disputing the Character of the City: Heritage, Regeneration and the Urban Design Turn," London Journal of Canadian Studies 31, no.1 (2016): 113-30, https://doi.org/10.14324/111.444.ljcs.2016v31.008. ${ }^{36}$ There is a significant literature here, but helpful works include Ian McKay's The Quest of the Folk: Antimodernism and Cultural Selection in TwentiethCentury Nova Scotia (Montreal and Kingston: McGill-Queen's University Press, 1994); and McKay with Robin Bates, In the Province of History: Tourism and the Romance of the Past in Twentieth-Century Nova Scotia (Montreal and Kingston: McGill-Queen's University Press, 2010); Osborne, "The Road to Yesterday" (2009); Meaghan Beaton and Del Muise, "The Canso Causeway: Tartan Tourism, Industrial Development, and the Promise of Progress for Cape Breton," Acadiensis 37, no. 2 (2008): 39-69; Monica MacDonald, "Railway Tourism in the Land of Evangeline, 1882-1946," Acadiensis 35, no. 1 (2005): $158-80$.

My thinking about energy history has been shaped in particular by Sandwell, Powering Up Canada (2016); Christopher Jones, Routes of Power: Energy and Modern America (Cambridge, MA: Harvard University Press, 2014), https://doi.org/10.4159/harvard.9780674419612; Jerry Bannister, “A River Runs 
through It: Churchill Falls and the End of Newfoundland History," Acadiensis 41, no. 1 (2012): 211-25; and Alan MacEachern, The Institute of Man and Resources: An Environmental Fable (Charlottetown: Island Studies, 2003).

${ }^{37}$ See, for example, Michael Tutton, "Growing Frequency, Height of Nova Scotia Storm Surges Worries Mayor," CBC News, 5 March 2018, http://www.cbc.ca/news/canada/nova-scotia/nova-scotia-storm-surgesworries-queens-municipality-mayor-1.4563359; John Mazerolle, "Storm Surge Batters Coast from Shelburne County to Halifax,” CBC News, 3 March 2018, http://www.cbc.ca/news/canada/nova-scotia/lawrencetown-beach-road-closedstorm-surge-1.4560944; Hal Higgins, "Fortress of Louisbourg Prepares to Defend Itself against Floodwaters," CBC News, 20 September 2017, http://www.cbc.ca/news/canada/nova-scotia/climate-change-sea-level-stormsurge-flood-protection-historic-site-1.4298298.

${ }^{38}$ On Nova Scotia yachting in this era, see Caitlin Charman, “'An Ugly, Piled-Up Sea': Industrialization and Regional Identity in Hickman's Gulf of St. Lawrence Fiction," in The Greater Gulf: Environmental Histories on the Gulf of St. Lawrence, ed. Claire e. Campbell, Edward MacDonald, and Brian Payne (Montreal and Kingston: McGill-Queen's University Press, forthcoming 2019). The RNSYS moved its clubhouse further down the harbour during the construction of the terminals, and then to the quieter, non-industrial Northwest Arm-on the other side of the Halifax peninsula-in 1968.

${ }^{39}$ Eric Sager, "Wind Power: Sails, Mills, Pumps, and Turbines," in Sandwell, Powering $U p, 166$.

${ }^{40}$ On tall ships as industrial manufacture and investments, I thank the NEAR-EH discussants for stressing this point, and also found the work of Eric Sager and Gerald E. Panting, Maritime Capital: The Shipping Industry in Atlantic Canada, 1820-1914(Montreal and Kingston: McGill-Queen’s University Press, 1990) useful. Wind turbines, too, have benefited from romantic historical associations and antecedents. 